\title{
Erzurum'un İlk Kadın Milletvekili Nakiye Elgün'ün 5. Dönem TBMM'deki Faaliyetleri
}

\section{Activities of Nakiye Elgün Who Was the First Woman Deputy of Parliament from Erzurum In The 5th Period of The Grand National Assembly of Turkey}

\author{
Prof. Dr. Sadık SARISAMAN (D) 1
}

$\ddot{\mathbf{O} z}$

Nakiye Elgün 1882'de İstanbul'da doğmuştur. Rehberi Maarif Mektebi'nde başladığ öğrenim hayatı 1901 'de Darülmuallimattan mezuniyeti ile sona ermiştir. Öğretmenlik hayatına ise Darülmuallimat'ta başlamıştır. Ardından Sultan Ahmet İnas İdadi'sinde görev yapmıştır. Evkafa bağlı mekteplerde 1slahat çalışmaları yürütmüştür. Cemal Paşa'nın isteği üzerine Suriye'deki okullar için hazırlanan maarif programına katkı sağlamıştır. Özel okullardan Feyziye Mektepleri'ni teşkilatlandırmıştır.

Elgün cemiyetçilik çalışmalarında da bulunmuştur. Teali-i Nisvan Cemiyeti'nin kurucuları arasındadır. Şehit Ailelerine Yardım Birliği adlı bir teşkilat kurmuştur. Türk Ocağı'nda, Halkevlerinde, Tayyare Cemiyeti'nde, Himayei Etfal Cemiyetinde çeşitli görevler yapmıştır. 1930'da kadınlara belediye seçimlerine katılma hakkı verilince İstanbul Belediye Meclisi'ne seçilmiştir. Ardından 1934'de kadınlara ve seçme ve seçilme hakkı verilince 5. dönem TBMM'de Erzurum milletvekili olarak görev yapmıştır. 6 ve 7. dönemlerde de Erzurum'dan milletvekili seçilmiştir.

Elgün 5. dönem milletvekilliği süresince toplam 509 oylamaya katılmış ve bunların tamamında evet oyu kullanmıştır. Bu dönemde 7 konuşma ile en çok konuşma yapan kadın milletvekilleri arasına girmiştir. 2 önergede ve 2 kanun teklifinde imzası vardır. Dahiliye Encümeninde görev yapmıştır. Toplam 35 mazbatanın hazırlanmasına katkı sağlamıştır. 1946'da milletvekilliği sona erince emekli hayatı yaşamaya başlamış, bu dönemde yardım kuruluşlarında faaliyet göstermiştir. 23 Mart 1954 tarihinde İstanbul'da vefat etmiştir.

Anahtar Kelimeler: Nakiye Elgün, eğitim, Erzurum, Türkiye Büyük Millet Meclisi, parlamento tarihi, kadin

Makale Türü: Araştırma

\begin{abstract}
Nakiye Elgün was born in İstanbul in 1882. Her educational life starting at Rehberi Maarif School. ended with her graduation from Darülmuallimat in 1901. She started her duty as a teacher at Darülmuallimat. Then she worked at Sultan Ahmet İnas High School. She carried out reformation works in the schools under the pious foundations. At the request of Cemal Pasha, she contributed to the education program prepared for the schools in Syria. She organised Feyziye Schools that were among the private schools.

Elgün also performed association activities. She was among the founders of Teali-i Nisvan Association. She established an organization named Association of Aid for the Families of Martyrs. She carried out various duties at Türk Ocağı, Community Centres, Aeroplane Association, and Himayei Etfal Association. She was elected to the Istanbul Municipal Council when women were given the right to participate in municipal elections in 1930. Then she carried out the duty as a deputy from Erzurum in the $5^{\text {th }}$ period of
\end{abstract}

\footnotetext{
${ }^{1}$ Afyon Kocatepe Üniversitesi, Fen-Edebiyat Fakültesi, ssadik@aku.edu.tr.

Atıf için (to cite): Sarısaman, S. (2020). Erzurum'un ilk kadın milletvekili Nakiye Elgün'ün 5. Dönem TBMM'deki faaliyetleri. Afyon Kocatepe Üniversitesi Sosyal Bilimler Dergisi, 22(TBMM'nin 100. Yılı ve Millî İrade Özel Sayısı), 92-115.
} 
the Grand National Assembly of Turkey when women were enfranchised the right to vote and be elected was given to women in 1934. She was elected as a deputy from Erzurum also in the $6^{\text {th }}$ and $7^{\text {th }}$ periods.

During her duty as a deputy in the $5^{\text {th }}$ period, Elgün voted 509 times and voted "yes" in all of these votes. With 7 speeches, she was among the woman deputies who addressed speeches most during this period. There was her signature in 2 proposals and 2 legislative proposals. She worked in the Council of Internal Affairs. She contributed to the preparation of a total of 35 protocols of election. She was retired when her duty as a deputy ended in 1946, and she carried out activities in aid agencies during this period. She died in İstanbul on 23 March 1954.

Keywords: Nakiye Elgün, education, Erzurum, Grand National Assembly of Turkey, history of parliament, woman

Paper Type: Research

\section{Giriș}

Kadınlar genel olarak dünya tarihi boyunca erkeğin gerisinde kalmışlardır. Bu durum erkeğin kadına nazaran fiziken daha güçlü bulunması ile doğrudan ilgilidir. İlaveten geleneksel ve dini yaklaşımların da umumiyetle erkeği ön plana çıkardığı görülür.

$\mathrm{Bu}$ arada şu tespiti net bir şekilde ortaya koymak gerekir. Kadının geri planda kalması sadece İslam toplumu için geçerli değildir. Bütün dünyada durum aynıdır. Hatta, insan haklarının ve demokrasinin beşiği kabul edilen batı dünyasında da bir farklılık yoktur.

Bu şartlarda kadın hakları son yüzyılların meselesi olarak ortaya çıkmıştır. Her ne kadar batı dünyası önderlik yapmış görünse de orada da kadın hakları son dönemlerde önem kazanmıştır. Özellikle konumuzu teşkil eden seçme ve seçilme hususunda kadınların oy hakkı mücadelesi 1600'lü yıllarda başlamıştır. Bilindiği üzere dünyanın ilk demokrasilerinde kadınların oy hakkı bulunmuyordu. İlk demokrasiler asillerin egemen olduğu demokrasilerdi. Buralarda sadece asil erkekler oy kullanırdı, asil kadınların dahi oy hakları yoktu.

Öte yandan kadınların seçme ve seçilme mücadelesi 19. yüzyılda örgütlü bir şekilde yürütülmeye başlandı. Mücadele İngiltere ve Amerika Birleşik Devletleri'nde yoğunlaştıysa da kadınlara seçme hakkını tanıyan ilk ülke Yeni Zelenda oldu. Bu ülkede kadınlar 1893 yılında oy kullanmaya başladılar. Bunu Avustralya ve Finlandiya izledi. Avustralya'da 1902'de, Finlandiya'da 1906 'da kadınlara seçme hakkı verildi. Norveç'te 1913, Danimarka ve İzlanda'da 1915, Sovyetler Birliğinde ve Kanada'da 1917, Avusturya, Almanya ve İngiltere'de 1918'de, Amerika Birleşik Devletleri'nde 1920'de, Birmanya'da (Myanmar) 1922, Ekvator'da 1929 y1lında kadınlar oy kullandılar.

Türkiye'de ise kadınlara siyasi haklar aşamalı olarak verilmiştir. İlk aşama 20 Mart 1930 yılında çıkarılan Belediye Kanunu ile gerçekleşti. Kadınlar ilk defa belediye seçimlerinde oy kullanma ve belediye meclislerine üye seçilebilme hakkını elde ettiler. Bu çerçevede Yusufeli İlçesi belediye başkanlığına seçilen Sadiye Hanım Türkiye'de ilk kadın belediye Başkanı oldu.

İkinci aşamada 26 Ekim 1933 tarihinde Köy Kanunu'nda yapılan değişiklerle köylerde kadınlara da muhtar ve ihtiyar meclisine üye olma hakk1 verilmesidir. Türkiye'de seçimle Muhtarlık görevine gelen ilk kadın ise Gül Esin'dir. Gül Esin Aydın İli Çine İlçesi Karpuzlu Bucağı'nda muhtar seçilmiştir.

Son aşama ise 5 Aralık 1934'te kadınlara milletvekili seçme ve seçilme hakkının verilmesidir. Türkiye, kadınlara milletvekili seçme ve seçilme hakkını veren ilk ülkeler arasında yer almıştır. Bu tarihte henüz Fransa, İtalya gibi bazı batı ülkeleri bile kadınlara seçme ve seçilme hakkı vermemişlerdi.

$\mathrm{Bu}$ araştırmanın amacı Türkiye'de kadın haklarının uygulanması konusunun anlaşılmasına katkı sağlamaktır. Bu anlamada ilk kadın milletvekillerinden Nakiye Elgün'ün 
seçilmesi ve meclisteki faaliyetlerini somut ve objektif bir şekilde ortaya koymaktır. Nakiye Elgün özelinde kadınların kendilerine verilen hakları ne derece sahiplenebildiklerini ortaya koymaktır.

Araştırmanın kapsamı Nakiye Elgün'ün 5. dönem milletvekilliği ile sınırlıdır. O'nun 6. ve 7. dönem meclis faaliyetleri araştırmanın kapsamı dışındadır. Yine O'nun Türk eğitim tarihine katkıları, çeşitli yardım cemiyetlerindeki faaliyetleri araştırmaya dahil değildir.

Araştırma'nın temel kaynağı Türkiye Büyük Millet Meclis zabıtlarıdır. Türkiye Büyük Millet Meclisi Arşivi ve Cumhuriyet Arşivi gibi arşivlerden de yararlanılmıştır. Dönemin gazeteleri çalışmaya ciddi manada katkı sağlamıştır. Araştırmada Elgün hakkında yazılmış ya da dolaylı olarak ondan bahseden yayınlar da kullanılmıştır.

\section{Biyografisi}

1882 'de İstanbul'da doğmuştur. Babası Sivaslı Gedikoğullarından Mehmed Ali Efendi (Gövsa, 1946, s. 112), annesi Zeliha Hanım'dır (TBMM Arşivi, Tercümei Hal, Dosya No: 21). Dört buçuk yaşında kaydolduğu Rehberi Maarif adındaki özel bir okulda öğrenim hayatına başlamıştır. Buradan mezun olduktan sonra İstanbul'daki Darülmuallimat'a kaydolmuştur (Önen, 1935, s. 1-9). 1901'de Darülmuallimatı bitirmiş (Gövsa, 1946, s.112.)² 1902 yılında aynı okulda 75 lira maaşla öğretmen yardımcısı olarak göreve başlamıştır. İlerleyen yıllarda okulda yeni görevler de almıştır. 1908'de katipliğe, 25 Eylül 1909'dan itibaren de müdür yardımcılığına getirilmiştir (M. Öztürk, 2014, s. 32).1911 yılına kadar buradaki görevine devam etmiştir (Önen, 1935, s. 1-9).

İkinci Meşrutiyet'in ilanından sonra 1911 yllında İstanbul'da Sultanahmet'te rüştiye üstüne üç yıl eğitim veren İnas İdadisi açılmıştı (C. Öztürk, 2012, s. 466). Elgün buraya müdür yardımcısı olarak tayin edilmiştir (Önen, 1935, s. 1-9). Bilahare 1914 yılında bu mektep tamamen yeni bir binada yatılıya çevrilmek istenmiş, Nakiye Elgün de müdür yardımcılı̆̆ından alınarak ders nazırı yapılmıştır. İdadi'nin müdürlüğüne Abravaya adında Osmanlı vatandaşı Musevi bir bayan öğretmen tayin edilmiştir. Elgün, yeni müdire ile eğitim öğretim yöntemleri konusunda fikir ayrıllğına düşünce idadideki görevinden istifa etmiştir (Güneş, 2001, s. 271; Duroğlu, 2007, s. 87; Önen, 1935, s. 1-9; M. Öztürk, 2014, s. 34-35).

Nakiye Elgün 1914-1917 yılları arasında ise Vakıf Mektepleri'nin 1slahı ve düzenlemesiyle uğraşmıştır (Duroğlu, 2007, s. 87-88). O zaman Evkaf Nazırı olan Mustafa Hayri Efendi evkafa ait mahalle mekteplerinde yenilik yapmak istemiş ve Nakiye Elgün'e tamamen serbest çalışacağı, işine karışılmayacağı vaadi ile görev teklif etmiştir. O da bu teklifi kabul ederek çalışmaya başlamıştır. Beyoğlu da dahil olmak üzere İstanbul'da Anadolu ve Rumeli sahilindeki ve merkezdeki bazı binaları okula dönüştürmüş, öğretmen kadrolarını kendisi oluşturmuştur. Bu hazırlıklar tamamlandıktan sonra civardaki bütün mahalle mekteplerini de kapattırmıştır. Kapatılan mahalle mekteplerindeki öğrencileri yeni açtığı okullara almıştır. Başlangıçta üç sınıflı ilkokul halinde tesis edilen bu mektepler her sene bir sinıf ilavesi ile tam devreli bir okul haline getirilmiş, şube sayıları artırılmıştır. Bu şekilde açılan 15 mektebin yönetimi Nakiye Elgün'e verilmiştir. Bu mekteplerin hepsinde aynı program uygulanmıştır. Aynı gün ve saatte bütün okullarda aynı dersler okutulmuştur. Mekteplerde aynı dersler aynı ölçü ve şekilde verilmiş, sayısı binlere varan öğrencilere aynı şarkılar öğretilmiştir. Mekteplerin hepsi pazartesi günü ve perşembe öğleden sonra tatil edilmiştir.

Ancak Şubat 1917'de Sait Halim Paşa yerine Talat Paşa sadrazamlık görevine getirilince Mustafa Sabri Efendi'nin Evkaf Nazırlığı görevi sona ermiştir. Bu durum Nakiye Elgün'ün düzenlediği evkaf okullarını da etkilemiştir. Yeni maarif nazırı bu mekteplerin milli eğitim bakanlığına devredilmesini sağlamıştır. Elgün, bunun üzerine görevinden istifa etmiştir. O'nun

\footnotetext{
${ }^{2}$ Elgün bir gazeteye verdiği röportajda Darülmuallimattan mezuniyet tarihini R.1315, yani miladi 1899 olarak belirtmiştir. Bkz Önen, a.g.m, s.1-9.
} 
ifadesiyle üç yıldır birçok zahmetlerle elde edebildiği okullarındaki vahdet böylece kaybolup gitmiştir (Önen, 1935, s. 1-9).

$\mathrm{Bu}$ arada Nakiye Elgün Birinci Dünya savaşı sırasında Cemal Paşa'nın Suriye'deki Arap ayrılıkçı hareketlere karşı oluşturmak istediği okulların planlanması çalışmalarında da bulunmuştur. Cemal Paşa 1916 yılı yazında Halide Edip ve Nakiye Elgün'ü Suriye'ye davet etmiști. Onlar okullar konusundaki incelemelerini tamamlayarak bir maarif programı hazırlamışlardır. Buna göre Lübnan, Beyrut ve Şam vilayetleri ortak bir eğitim sistemi altında birleştirilecektir. $\mathrm{Bu}$ üç vilayet için bir muallim mektebi açılacaktır. Üç vilayetin her birinde görevi idadilere ve kolejlere hazırlamak olan altı sınıflı birer ilkokul açılacaktır. Okullarda Türkçe, Arapça ve Fransizca olmak üzere üç dil öğretilecektir (M. Öztürk, 2014, s. 38-41).

Diğer taraftan $\mathrm{O}$, evkaf okulları tecrübesinden sonra "Resmi mektep hayatında benim için vazife kalmamıştı" demiş ve özel okullara yönelmiştir. "Yeni Mektep" adı altında faaliyet gösteren bir özel okulun müdürü görevinden ayrılınca Nakiye Elgün'e teklif götürmüşlerdir. O, müdürlük görevini kabul ederek bu okulu "Feyziye" adı altında yeniden teşkilatlandırmıştır. İlkokul olarak kurulan bu mektebe her sene bir sınıf ilave ederek ortaokul ve nihayet lise haline getirmiştir. Bu okulun ilkokul kısmında olduğu gibi ilave edilen her sınıfı da muhtelit olarak eğitim öğretime devam etmiştir. Böylece Türkiye'de ilk defa orta öğretimde muhtelit sistem uygulanmıştır (Önen, 1935s. 1,9). O, Feyziye mekteplerinde görev yaparken 1920 yılı itibarıyla İstanbul Muallimler Cemiyeti Başkanı idi (Afetinan, 1982, s. 121). Bir araştırmaya göre bu sıralarda O, Milli eğitim müfettişliği de yapmıştır (Kurnaz, 1992, s. 137).

Elgün, 11 yıl kadar Feyziye Mektebi'nde görev yapmış, daha sonra buradan istifa ederek bir yıl dinlenmiştir. Ardından 1929'da tekrar çalışma hayatına dönerek İstanbul Kız Lisesi müdürlüğüne tayin edilmiştir (Duroğlu, 2007, s. 87-88, Önen, 1935, s. 1-9). Eğitime katkılarından dolayı Milli Eğitim bakanlığı tarafından kendisine Fazilet mükafatı verilmiştir (Gövsa, 1946, s. 112).

Bu sırada 1930 yılında Taksim Meydanı'nda dünyada ilk kez çocukların da pankartlarıyla eşlik ettiği bir çocuk mitingi düzenlemiştir. Çocuklar tarafindan taşınan pankartlarda "hava, güneş ve hürriyet isteriz.", "azarlanmamak isteriz.", "hürmet isteriz.", “yalnız uyumak isteriz.", "sağlam ana baba isteriz.", "öpülmemek isteriz.", "adalet isteriz." gibi çocukların talepler yer almıştır. Ardından da Türkiye'de ilk defa Nakiye Elgün tarafından Çocuk Hakları Bildirisi okunmuştur (Nakiye Elgün İ.Ç.H.B.Y, 2020)33.

Görüldüğü üzere Nakiye Elgün'ün eğitimci kişiliği en önemli yönünü oluşturur. Fakat, o kendisini sadece eğitimle sınırlandırmamıştır. Topluma faydalı olmayı, aydınlatmayı görev edindiği için dernek faaliyetleri içerisinde de yoğun bir şekilde yer almıştır.

İkinci Meşrutiyetin ilanından sonra 1909 yılında kurulan Teali-i Nisvan Cemiyeti'nin kurucuları arasındadır (Avc1, 2016, s. 238) ${ }^{4}$. O'nun ifadesiyle bu cemiyetin kurulma nedeni Türk kadınına ilmi ve sosyal alanlarda yardım etmektir. Elgün cemiyetin umumi katipliğini de yapmıştır. Balkan Savaşı'nda cemiyetin Cağaloğlu'nda açtığı bir hastaneyi yönetmiş ve yaralı askerlere hizmet etmiştir (Önen, 1935, s.1,9). Yine Balkan Savaşı sırasında bir yardım cemiyeti olarak kurulan Müdafaa-i Milliye Osmanlı Hanımlar Cemiyeti'nde de faaliyet göstermiştir (Kurnaz,1992, s. 117).

O'nun çalışmalarına katıldığı derneklerden birisi de Türk Ocaklarıdır. Elgün, "yurdun sahibi olan Türk'ün hakkını müdafaa için" bu derneğe üye olduğunu belirtmiştir. Türk Ocă̆ı'nda kürsüye çıkarak konferans veren ilk kadınlar arasındadır (Önen, 1935, s. 1-9).

\footnotetext{
31923 yılında yayımlanan Cenevre Çocuk Hakları Bildirgesi 1924 yılında Milletler Cemiyeti tarafindan da onaylanarak yayınlanmıştır. bkz. http://www.cocukhaklariizleme.org/cocuk-haklarinin-tarihcesi (ET: 10 Nisan 2020)

${ }^{4}$ Bu cemiyetin kuruluş tarihini Șefika Kurnaz 1908 olarak göstermiștir. Bkz. Kurnaz,a.g.e, s. 112.
} 
Nakiye Elgün, Birinci Dünya Savaşı sırasında Hilali Ahmer Cemiyeti'nde de görev yapmıştır (Önen, 1935, s. 1,9). 1915 yılında şehit ailelerini himaye için Şehit Ailelerine Yardım Birliği adlı bir teşkilat kurmuştur ${ }^{5}$. Burada şehit ailelerine maaş bağlanması, yetimlerin okula yerleştirilmesi gibi hizmetler verilmiştir (Avc1, 2016, s. 242). Bu teşkilat İstiklal Savaş1 başladıktan sonra da Şehit Ailelerine Yardım Cemiyeti adı altında faaliyet göstermiştir. Cemiyet şehit ailelerine çeşitli yardımlarda bulunmuş, bazı ailelere ayda kırkar lira maaş vermiştir

Nakiye Elgün'ün cemiyetçilik faaliyetleri cumhuriyet döneminde de devam etmiştir. Türk kadınları çalıştırma yurdunda görev almıştır. Milli İktisat ve Tasarruf Cemiyeti İstanbul şubesinin kurucularındandır (Önen, 1935, s. 1-9). Bu çerçevede 1929 Dünya ekonomik bunalımının Türkiye'ye etkilerini bertaraf etmek amacıyla yapılan etkinliklere katılmıştır. Milli İktisat ve Tasarruf Cemiyeti tarafından Darülfünunda düzenlenen konferanslarda o da konuşmuştur. Nakiye Hanım bu mücadeleye katkı sağlamanın vatan borcu olduğunu, Türk kadının göreve her zaman hazır bulunduğunu ifade etmiştir (Yalçın, 2019, s. 88).

O, Türk Tayyare Cemiyeti'nin İstanbul şubesini kuranlardandır. Cemiyetin başkanlığını uzun süre yürütmüştür. Milletvekili seçilince başkanlıktan ayrılmıştır. Tayyare Cemiyeti İstanbul Şubesi hizmetleri nedeni ile kendisine altın madalya vermiştir (Önen, 1935, s. 1-9).

20 Ocak 1931 tarihinde kurulan Topkapı Türk Fukaraperver Hayır Müesesesi'nin 8 kurucu üyesinden birisidir. 1938 yılından itibaren de bu hayır kurumunun başkanlığını yapmaya başlamıştır (Topkapı Fukaraperver Cemiyeti, 2008, s. 13-32). Cemiyeti'nin 1932 yılında halkevleri kurulduktan sonra bu kuruluşta da yoğun hizmetleri olmuştur. İstanbul Halkevi idare heyetinde fahri muhasiplik yaptığı gibi halk dershaneleri kolu başkanlığını da yürütmüştür.

O, sosyal ve ilmi toplantılarda sıklıkla görülürdü. Şehitlikleri ziyarete giden heyetler arasında, Çanakkale ve Büyük Taarruz gibi Türk zaferlerinin anıldığı toplantılarda bazen dinleyici bazen de hatip olarak bulunurdu. Ne dondurucu soğuklara ne de yakıcı sıcaklara aldırmaz halkı aydınlatmak için oradan oraya koşardı (Önen, 1935, s. 1-9).

Nakiye Elgün, milletvekilliği döneminde de çeşitli yerlerde halkı aydınlatıcı konferanslar vermeye devam etmiştir. Örneğin 15 Şubat 1938 günü Notre Dame de Sion Fransız Kız Lisesi'nde "Çocuk Terbiyesi" hakkında Türkçe bir konferans vermiştir (Cumhuriyet, 15 Şubat 1938, s. 8).

Yine $\mathrm{O}$, milletvekilli seçildikten sonra da derneklerdeki çalışmalarını devam ettirmiştir. İstanbul'da düzenlenen 12. Uluslararası Kadın Kongresi'ne katılmıştır. Bir gazete haberinde belirtildiğine göre kadın milletvekilleri Nakiye Elgün'ün etrafına dizilmişlerdi (Akşam, 19 Nisan 1935, s. 7) Türkiye'nin ilk kadın milletvekilleri kongreye takdim edildiklerinde büyük alkış almışlardı (Kurun, 19 Nisan 1935, s. 8).

Elgün'ün faaliyet gösterdiği cemiyetlerden birisi de Himayei Etfal Kadın Yardım Cemiyetidir. Bu cemiyetin 24 Mart 1935 tarihinde gerçekleşen dördüncü kongresinde başkanlığa seçilmiştir. Cemiyet bu kongrede adını değiştirerek Kadın Esirgeme Kurumu'na da dönüştürmüştür (Ulus, 25 Mart 1935, s. 3).

Elgün, 25 Mayıs 1935'te Türk Hava Kurumu'nun 6. Kurultayı'nda Türk Hava Kurumu'nun Genel Merkez Kurulu üyeliğine getirilmiştir. O, 30 kişiden oluşan genel merkezin tek kadın asil üyesidir. Elgün aynı zamanda Merkez Yönetim Kurulu üyeliğine de getirilmiştir. 11 kişilik yönetim kurulunun tek bayan üyesi odur (Ulus, 26 Mayıs 1935: 6).

13 Haziran 1936 tarihinde toplanan Çocuk Esirgeme Kurumu genel Kongresi'nde bu kurumun Umumi Merkez Heyeti üyeliğine seçilmiştir (Ulus, 14 Haziran 1936, s. 1) Üçüncü Türk Dil Kurultayı'nda Tüzük Komisyonu’nda da görev yapmıştır (Üçüncü Türk Dil Kurultayı, 1937, s. 33).

\footnotetext{
${ }^{5}$ Kurnaz bu cemiyet için 1918 yılına işaret etmektedir. Cemiyetin kuruluşunun Büyük Harpten sonra olduğunu yazmıştır. Bkz. Kurnaz, a.g.e, , s. 119.
} 
Öte yandan Nakiye Elgün, Anadolu'da Milli Mücadele başladığında yardım ve iş birliğinde bulunmuştu. Seniha Nafız, Anadolu'da çarpışan subaylarla Ankara'daki siyaset adamlarından bir kısmının İstanbul'daki ailelerine onun aracılığı ile para gönderdiklerini, ayrıca müdürlüğünü yaptığı Feyziye Okulu'nun depolarında, Bartın üzerinden Anadolu'ya sevk edilen savaş malzemelerinin bir kısmının sakladığını belirtmiştir (M. Öztürk,2014, s. 44).

Yine O'nun Milli Mücadele döneminde çeşitli toplantılarda etkili konuşmaları da söz konusudur. Bunlardan bir tanesi İzmir'in işgali dolayısıyladır. İşgal 21 Mayıs 1919'da Darülfünun'da toplanan öğretmenler tarafından protesto edilmişti. Bu mitingde Nakiye Elgün de bir konuşma yapmıştır. O, konuşmasında öncelikle adil bir barış anlaşmasının yapılacağını beklerken İzmir'in işgali ile karşılaşıldığını hatırlatmıştır. Hakim milletin esir mertebesine indirilmeye çalışıldığ boyayarak Türk sancă̆ının hakim olacağını ispat edeceğiz. Türk başı yukarıda yaşadı, alameti farikasinı semadan intihap etti, başka sancă̆a baş ĕgmeyecektir. Ĕger bizi feda etmek istiyorlarsa şanlı bir surette ölmeğe hazırı. Ben cesur milletimin imanlı kadınları namına diyorum ki, Avrupa Türklerle meskun herhangi bir yeri Yunan'a vermek isterse hepimiz hep beraber şanlı bir surette ölmeğe karar verdik" demiştir (Şapolyo, 1968, s. 22-23).

İkinci konuşmasını ise 13 Ocak 1920 tarihinde Sultanahmet Meydanı'nda gerçekleştirilen bir mitingde yapmıştır. Bu mitingin yapılma sebebi İstanbul'un İtilaf Devletleri tarafından işgal edileceğine dair duyumlar olmuştur. Söz konusu mitingde Nakiye (Elgün) de bir konuşma yapmıştır. O, öncelikle azim ve imanla dolu Türk kadınlığının bir ferdi sıfatıyla söz aldığını belirtmiştir. Ülkenin üzerinde hüzün ve ayrılık bulutları dolaştığını hatırlatmış, İtilaf Devletleri'nin bu derece kahredici bir karar alacaklarına ihtimal vermediklerini söylemiştir. Büyük bir milli felaket karşısında bulunulduğunu ifade etmiştir. Türk milletinin hafife alındığını, sabrının zorlandığını, ağırbaşlılığının küçümsendiğini, temel haklarının elinden alınmaya çalışıldığını belirtmiştir.

$\mathrm{O}$, Türklerle meskun araziden artık bir karış bile fedakarlık yapılamayacağını belirterek "İzmir'i, İstanbul'u siyasi ve idari nokta-i nazardan vermek bizim için kabil değildir" demiştir. Elgün Türklerin başka milletlerin haklarına tecavüz etmedikleri gibi, kendi haklarını da kesinlikle sonuna kadar koruyacaklarını bildirmiştir. İslam aleminde Anadolu'nun özel bir yeri bulunduğunu, Müslümanların beş asırdan beri Osmanlı saltanat ve hilafeti aracılı̆̆ıyla İstanbul'dan himaye edildiğini hatırlatmıştır. Dünya Müslümanlarını kendisine bağlayabilecek başka bir güç ve makamın olamayacağını iddia etmiştir.

Elgün, konuşmasında İstanbul'un önemine ve vatan sevgisine de işaret etmiştir. Türk kadınının Çanakkale muharebelerinde evladının sinelerinden siperler teşkil ettiğini belirterek şunları söylemiştir: "Efendiler size memleketin bir kadını sıfatıyla hitap ediyorum. Fatih'in, Selim'in, Süleyman'ın mezarlarını, ecdadının ebedî abideleri olan camileri, türbeleri bırakıp çıkacak içinizde bir erkek var mıdır? Ben tasavvur etmiyorum. Çıkmayacaksınız, bırakmayacaksınız. Biz de daima sizinle beraber olacağız, yanınızdan önünüzden ayrılmayacağız. Hayatından ziyade sevdiği evladını vatan sevgisine feda eden kadınlarımızın can ile sevdiği İstanbul'a canını feda edeceğine elbette inanırsını"

Elgün, haktan başka bir kuvvete dayanmayan Türk milletinin Allah'ın lütuf ve himayesi sayesinde asla davasından vaz geçmeyeceğini özellikle vurgulamıştır. Konuşmasını ya istiklal ya ölüm anlamına gelen şu cümle ile son vermiştir. " Önünüzde açık iki yol var: biri, tarihimize şanımızla devam etmek, diğeri gözlerimizle beraber tarihimizi de kapayıp ebediyete götürmektir" (Afetinan, 1982:121-122).

Nakiye Hanım, 16 Ocak 1920'de kendisiyle yapılan bir mülâkatta da Anadolu kadınlarını övücü ifadeler kullanmıştır. O, Anadolu ile İstanbul kadınları arasında bir kıyaslama yapmış, İstanbul kadınlarının savaş yıllarında yaptığı fedakârlıkları "biraz süslü" bulduğunu dile getirmiştir. Anadolu kadınlarının savaş yıllarında vatan için evladını, kocasını, malını, mülkünü, her şeyini feda ettiğini söylemiştir. Erkelerin cephede olması nedeni ile boş kalan tarlalarda 
kadınların çalıştığını hatırlatmıştır. Türk kadınlarının dünyanın diğer milletlerinin kadınlarına nispetle daha fedakar olduklarına işaretle şunları söylemiştir: "Haydi, bu hareketleri her milletin hamiyetli kadınları için tabiî bir hal olarak kabul edelim. Fakat muharebede askere erzak, cephane taşımak, hatta bizzat harp etmek yalnız Türk kadınlarında görülen celâdet ve vatanperverlik numuneleridir. Son İzmir hadiselerinde vatan için silaha sarlan zeybek kadınlartyla bütün Türkiye iftihar etse yeridir.” (Duroğlu, 2007, s.89).

Elgün'ün siyasi hayatı ise Türkiye'de kadınlara siyasal hakların verilmesi ile paraleldir. 1930'da kadınlara belediye seçimlerine katılma hakk1 verilince Elgün, İstanbul Lisesi'ndeki görevinden ayrılarak İstanbul Belediyesi Meclis-i Umumi üyeliğine aday olmuş ve seçilmiştir." (Duroğlu, 2007, s. 89; Önen, 1935, s. 1-9). O, 1934 belediye seçimlerinde de yine İstanbul Umumi Meclisi ve Daimi Encümeni'ne seçilmiş ve bu görevi milletvekili olana kadar sürdürmüştür (Duroğlu, 2007, s. 87-89. İstanbul Belediye Meclisi'nde ilk söz alan kadın üye unvanı ondadır (Topçuoğlu, 1984, s. 96). Belediye Encümeninin en çok çalı̧̧an üyelerindendi. Encümen toplantılarında şiddetli tartışmalara katılır, bazen gece yarılarına kadar çalışırdı (Önen, 1935, s. $1-9)$.

Nakiye Elgün 5 Aralık 1934'de kadınlara ve seçme ve seçilme hakkı verilince milletvekilliği aday adaylığına başvurmuş̧tur. Erzurum'dan aday gösterilmiş 5. dönem TBMM'de Erzurum milletvekili olarak görev yapmıştır. 6 ve 7. dönemlerde de Erzurum'dan milletvekili seçilmiştir. Dolayısıyla Elgün 1935'den 1946 yılına kadar 11 yıl Erzurum milletvekilliği yapmıştır.

$\mathrm{O}$, milletvekilliği sonrasında yeniden öğretmenliğe dönmemiştir. Topkapı Fukaraperver Cemiyeti'nin Başkanlığını sürdürmüştür. Bu görevini 1953 yılına kadar devam ettirmiştir (Topkap1 Fukaraperver Cemiyeti, 2008, s. 32; Milliyet, 24 Mart 1954, s. 7).

Nakiye Elgün hayatı boyunca hiç evlenmemiştir. Ömrünü ülkesine ve halka hizmete adamıştır. $\mathrm{O}$, evlenerek topluma hizmetten geri kalmak cesaretini gösterememiştir. Bekar kalmasının hikayesini şöyle anlatır: "... Aşktan falan inkisara uğramış değilim ve bekârlığım bu yüzden değildir. Genç kızlık çağında birçok taliplerim çıktı. Fakat ben, mektebi bitirdikten sonra içtimai sahada çalışmaya başladığım için, evlenmeye bir türlü yanaşmadım. Her isteyenim çıktığında, ben bu işi gereği gibi yürütebilir miyim?' diye uzun uzun düşündüm. Evlendiğim takdirde ya evimi, yahut da sosyal konulardaki çalışmamı aksatacağımı düşünerek, endişe ediyordum, ikisinden birinin tercihi hususunda kendimi zorladı̆̆ım zaman, sosyal alanda çallşmayı evliliğin üstünde buldum, işte bu nedenle evlenmedim ve bekâr kaldım." (Toros, 1986, s. 9).

Elgün 23 Mart 1954 tarihinde İstanbul'da vefat etmiştir. Ölümü 24 Mart 1954 Milliyet gazetesinde haber yapılmıştır. Bu haberde "Ilk kadın mebuslarımızdan Erzurum sabık mebusu bayan Nakiye Elgün dün sabah vefat etmiştir. İstanbul Belediye Meclis azaliğında bulunmuşve birçok hayır cemiyetlerinde vazife almış olan ve son olarak Topkapı Fakirlere Yardım Yurdu başkanı olan Nakiye Elgün'ün cenazesi bugün öğle namazını müteakip Şişli camiinden kaldırılacaktır" şeklinde kamuoyuna duyurulmuştur (Milliyet, 24 Mart 1954, s. 7). Cumhuriyet gazetesinde de "Acı Bir Kayıp Nakiye Elgün dün vefat etti " başlığ ile okuyucuya duyurulmuştur. Haberde Elgün'ün tutulduğu amansız hastalıktan kurtulamadığı belirtilmiştir Cumhuriyet, 24 Mart 1954, s. 1-4).

Cenaze törenine İstanbul valilisi ve belediye başkanı Prof. Fahrettin Kerim Gökay, Türk Ocağı ve Fukaraperver Cemiyeti üyeleri ve yakın dost ve akrabaları katılmışlardır. Şişli Camii'nden alınan naaşı Zincirlikuyu Asri Mezarlığı'na defnedilmiştir (Milliyet, 25 Mart 1954, s. 6). Halen burada metfundur. 


\section{Milletvekili Seçilmesi}

Nakiye Elgün kadınlara seçme ve seçilme haklarının verilmesini taktirle karşılamıştır. O, Kadınların köy muhtarlı̆̆ına ve ihtiyar heyeti azalığına seçilmesine dair olan kanunun 26 Ekim 1933 tarihinde mecliste kabul edilmesinden sonra Cumhuriyet Halk Fırkası İstanbul merkezine teşekkür mektubu göndermiştir. Mektubunda şehir kadınlarına önceden verilmiş olan intihap hakkının bu defa köy kadınlarına da verilmesinden duyduğu memnuniyeti dile getirmiştir (Akşam, 28 Ekim 1933, s. 2).

Kadınlara seçme ve seçilme hakkının verilmesi üzerine Kadınlar Birliği tarafından 7 Aralık 1934'te İstanbul'da gerçekleştirilen mitinginde de bir konuşma yapmıştır. Konuşmasında mitingin gerçekleştirildiği Bayezid meydanını kastederek "Ben bu meydanın ne kara günlerini gördüm. Düşman tayyarelerinin bu ufuklarda dolaştı̆̆ günleri gördüm. İsgal ordularının şu kaplya süngülü askerler diktiğini gördüm. Şimdi de bu mutlu, bu kıvançlı günü görüyorum. Bize verilen büyük haklar, büyük hürriyetler karşısında ne yapsak azdır" demiştir (Akşam, 8 Aralık 1934, s. 4).

Öte yandan kadınlara milletvekili seçme ve seçilme hakkı verilince aday adaylığını koyan Nakiye Elgün basına verdiği demeçte "kadın saylavın isteyecek bir şeyi kalmadı ki. Ne hakkımız varsa verildi" şeklinde bir açıklama yapmıştır (Cumhuriyet, 26 Ocak 1935:1). O ayrıca Taksim Abidesi önünde sandıklar hareket etmeden evvel yaptığı konuşmada demiştir ki: "Yüzlerce yıl acun ülkelerine kanat açan, yer yüzü uluslarına önderlik yapan büyük soyumun altın tarihi Samsun'da doğan ve bütün Türk eline ışığını salan bir güneşin altında yeniden parlamış gene, dipdiri bir Türk devleti olarak canlanmış ve yeniden hızlanmıştır" (Son Posta, 9 Şubat 1935, s. $3)$.

$\mathrm{Bu}$ sırada o aynı zamanda İstanbul'da milletvekili seçimi teftiş kurulu üyeliği de yapmıştır. Kurul üyesi olarak Beyoğlu'nda yapılan seçim hazırlıklarını teftişle görevlendirilmiştir (Cumhuriyet, 14 Ocak 1935, s. 2).

Diğer taraftan Nakiye Elgün Cumhuriyet Halk Fırkası Genel Merkezi tarafından Erzurum'dan milletvekili adayı olarak gösterilmiştir. Nakiye Elgün'ün milletvekili adayı yapılma nedeni dönemin en önemli aydın ve kültürlü kadınları arasında yer almış olmasıdır. O'nun eğitim alanındaki hizmetleri meşhurdu. Birçok dernekte de faaliyet göstermiş ünlü bir kişi idi.

Diğer taraftan Nakiye Elgün'ün bu zamana kadar Erzurum ile hiçbir ilgisi olmamıştır. Bu durum demokratik faydaya engeldir. Zira, milletvekillerinin öncelikle temsil ettikleri yöreyi yakından tanımaları gerekir. Ancak, adayların belirlenmesine CHP yerel idareleri yeterince söz sahibi değillerdi. Aksi takdirde benzer şartları taşıyan Erzurumlu bir bayanın milletvekili adayı yapılması kuvvetle muhtemeldi.

Nihayetinde seçimler tamamlanmış, Nakiye Elgün 870 ikinci seçmen oyu ile 5. Dönem Türkiye Büyük Millet Meclisi'ne Erzurum milletvekili seçilmiştir. O'nun milletvekili seçildiğini gösteren mazbatası 14 Şubat 1935 tarihlidir (TBMM Arşivi, Kutu: 23, Dosya, 904) O, basına verdiği demeçte "Gayem emelim şimdiye kadar olduğu gibi bundan sonra da memleket millet için çalışmaktır. Orada da Türk'e Türk kadınına minnet borcumu ödemeye çalışacağım" demiştir (Önen, 1935, s. 1-9). İstanbul'dan ayrılmadan evvel 23 Şubat 1935 günü halkevinde bir çay ziyafeti verilmiştir (Cumhuriyet, 24 Şubat 1935, s. 2). Yine İstanbul Halkevi onun Erzurum milletvekili sıfatı ile şehirden ayrılmasından evvel şerefine bir yemekli toplantı tertip etmiştir (Cumhuriyet, 23 Şubat 1935, s. 2).

1 Mart 1935 Cuma günü saat 14.00'de 5. Dönem Türkiye Büyük Millet Meclisi açılmıştır. Nakiye Elgün de diğer kadın milletvekilleri gibi ilk günkü meclisin açılış toplantısına katılmıştır. Kadın milletvekillerinin hepsi başları açı olarak gelmişlerdir. Çoğunluğu siyah kostüm tayyör giymişler, kravat bağlamışlardır. Bütün bayan milletvekillerine birer erkek vekil refakat etmişti. Nakiye Elgün'e de Giresun Milletvekili Hakkı Tarık Us eşlik etmişti (Kurun, 2 Mart 1935, s. 4). 
İlk gün ant içen milletvekilleri arasında Nakiye Elgün de vardı (TBMM.ZC, 1 Mart 1935, s. 5-7) O'nun milletvekili seçildiğini gösterir mazbatası 7 Mart 1935 tarihinde TBMM Genel kurulunda oylanarak kabul edilmiştir TBMM.ZC, 7 Mart 1935, s. 13-23).

\section{Meclisteki Konuşmaları}

Erzurum Milletvekili Nakiye Elgün de 7 konuşma yapan kadın milletvekillerindendir. Elgün'ün ilk konuşması İsmet İnönü Hükümeti'ne güvenoyu verilmesi dolayısıyladır. O, Türkiye'de mecliste bulunma ve hükümete güvenoyu verme onurunun kadınlara ilk defa verilmiş olmasından duyduğu memnuniyeti dil getirmiştir. Bugünü "ulu gün" olarak tanımlamış, Türk milletine başarılar ve saadetler dilemiştir. Bu vesile ile Gazi Mustafa Kemal Paşa'ya teşekkür etmiş ve duyduğu heyecanı dile getirerek "Bütün dünya bilsin ki Türk milleti dün olduğu gibi bugün de, bugünden sonra da hiç eksiksiz bir bütün olarak çalışacaktır" demiştir (TBMM.ZC, 7 Mart 1935, s. 32).

Elgün'ün ikinci konuşması Boğazların tabi olacağı usule dair mukavelenamenin yerine kaim olmak üzere Montrö'de imza edilmiş bulunan yeni mukavelenamenin tasdikine dair kanun münasebeti iledir. O, Montrö'yü Gazi Mustafa Kemal Atatürk'ün işaret vermesi ile başarılan büyük bir zafer olarak değerlendirmiştir. Lozan'da açık kalan gediğin kapatıldığını ifade etmiştir. $\mathrm{Bu}$ vesile ile Türkiye'nin kayıtsız ve şartsız bağımsız, milli mukadderatına hakim dış politikasını övmüştür. Atatürk'ün Türk milletinin başından eksik olmamasını temenni etmiş, hür ve mesut Türk çocuklarının tam bir güven içinde Atatürk'ün yolundan ve izinden gideceklerine olan inancını dile getirmiştir. O, Montrö'yü aynı zamanda dünya güvenliğinin anahtarı olarak değerlendirerek şunları söylemiştir: "Bu zafer dolayısıyla, 13 seneden beri açık kalan kapılarımız artık düşmana, herkese karşı kapanmış bulunuyor ve Türkün kolu Mehmetçik de yine orada bekçilik ödevini eline almış bulunuyor. Boğazlar işi istediğimiz ve dilediğimiz gibi hallolundu.. Montrö zaferi yalnız Türkün değil, ayn zamanda sulhun da bir zaferi olmuştur... Ne mutlu Türküm diyene" (TBMM.ZC, 31 Temmuz 1936, s .324-325).

O, Hatay muvaffakiyetinden dolayı açılan müzakere sırasında da söz almıştır. Konuşması kadın konuludur. Öncelikle Atatürk'ü Türk milletine kazandıran Zübeyde Hanım'ı sayg1 ve hürmetle zikretmiştir. Zübeyde hanım için "Türk milletinin kalbinde yatan bu büyük kadın" ifadesini kullanmıştır. Konuşmasında öncelikle erkek ya da kadın bütün Hataylılara selam göndermiş ve başarılar dilemiştir. Ancak, özellikle Hataylı kadınlara seslenmiştir. Türk kanı taşıdıklarını ve Türk kadını olduklarını unutmamaları gerektiğini söylemiştir. Türkiye Cumhuriyeti kadınlarının yolundan giderek, onlar gibi çok çalışmalarını, medeniyet yolundan ilerlemelerini, vatan için ölmeyi bilmelerini tavsiye ederek "Bugün Türk milletinin en büyük makamı olan bu kürsüden hem tavsiye ediyor ve hem bu günlerin tahakkuk edeceğini ümit ediyorum" demiştir (TBMM.ZC, 29 Ocak 1937, s. 173).

Elgün, Polis Teşkilat Kanunu görüşülürken 5 defa söz almıştır. Söz alma nedeni kanun teklifinin 56. maddesi hakkındaki Dahiliye Encümeninin teklifinin bütçe encümeni tarafından değiştirilmesidir. Bütçe encümeni bütçeye yük getireceği gerekçesi teklifi uygun bulmamıştır. Elgün söz konusu konuşmalarında önceden iki sınıfa ayrılan, 16 ve 20 lira maaş almaları kabul edilen polis memurlarının tamamının birinci sınıfa dahil edilmesini desteklemiştir. Bununla beraber polislerin bu haktan faydalanabilmeleri için okuldan ve enstitüden mezun olmaları gerektiği şartının eski polisleri mağdur ettiğine dikkati çekmiştir. Bu okullardan mezun olmayan görevdeki polislerin de gözetilmesini istemiştir. Bu durumda bulunan ve halen çalışmakta olan polislerden başarılı ve iyi sicil sahibi olanlarının küçük bile olsa zam almalarını talep ederek "Bunlar eğer bulundukları hizmette iyi sicil almış, amirlerinin takdirine mazhar olmuşlarsa, memlekete faydalı hizmetler ifa etmişlerse, bunlara otomatik olarak beş lira mi, üç lira mı, ne tensip ediyorsanız, o miktarl verelim, önlerine aşllmaz manialar koymayalım" demiştir (TBMM.ZC, 2 Haziran 1937, s. 20). 
Dahiliye Encümeni adına söz alan Şükrü Yaşın da Elgün'ü destekleyici ifadeler kullanmış, eski polis memurlarının mağdur edilmemesini istemiştir. İçişleri Bakanı Şükrü Kaya da Elgün'ü haklı bulmuş, ancak bütçe imkanlarının yetersizliğine de işaret etmiştir

Elgün bu konuşmaları çerçevesinde bir de önerge vermiştir. Söz konusu önerge ile belirtilen okullardan mezun olmadıkları halde en az altı sene hizmeti geçmiş olan polis memurlarına 5'er, komiserlere ise 8'er lira aylık tazminat verilmesini, bu tazminata her üç senede bir aynı miktarda zam yapılmasını, bu hükmün, kanunun uygulanmasından sonra aynı şartlarda mesleğe girenleri kapsamaması teklif edilmiştir. Önerge meclis genel kurulunda oylanmış, ancak kabul edilmemiştir (TBMM.ZC, 2 Haziran 1937: 13-20).

Nakiye Elgün, Cumhurbaşkanı Mustafa Kemal Atatürk'ün tasarruflarında bulunan bütün çiftliklerini hazineye bağışlaması hakkındaki tezkere münasebeti ile söz almıştır. O'nun konuşması Atatürk'e minnet duyguları ve teşekkür içeriklidir. Türk milletini kurtaran, yaşatan, ilerleten Gazi Mustafa Kemal'in şimdi de mal varlığını milletine bağışlama büyüklüğünü gösterdiğine işaret etmiştir. O, "Atatürk'ümüz bizim semamıza doğguğu günden beri her manevi sahada bize mütemadiyen nur, feyiz, ışık verdi. Yaşa Atatürk ve senin ideallerin uğrunda bütün Türk milleti onların tahakkuku için bütün kabiliyetini vermeğe ve senin için ölmeğe hazırdır." demiştir. O'nun milletin refahını, köylünün kalkınmasını hedef edindiğini ifade etmiştir. Türk milletinin de onun ölmeye ve idealleri uğrunda bütün varlığıyla çalışmaya hazır olduğunu dile getirmiştir (TBMM.ZC, 12 Haziran 1937, s. 271-272).

Elgün, 1938 senesi Maarif Vekaleti bütçesi görüşülürken uzun bir konuşma yapmıştır. O, bütçenin 550000 lirasının öğretmen maaşlarına ayrılmasını önemsemiştir. Derslerin vekil öğretmenlerden ve yardımcı muallimlerden alınarak ehil ellere verilmesini taktirle karşılamıştır. Gazi Terbiye Enstitüsü, Müzik ve Ertik Okulu'ndan ve Avrupa kurumlarından mezun olan öğretmenlerin hemen göreve başlatılmaları uygulamasını desteklemiştir. Bütçedeki 246000 liranın yeni 1.500 eğitmen yetiştirilmesine ayrılmasından memnuniyet duymuştur. Genel bütçeden 240.000 lirasının öğretmen maaşlarına tahsis edilmesini de eğitimin gelişmesi açısından faydalı bulmuştur. 124000 lira ile yatılı öğrenci sayısının 1000'den 1500'e çıkarılmasının de önemine de işaret etmiş, bu paranın \%75 i ile öğretmen yetiştirileceğini bildirmiştir. Yakın bir gelecekte bütün köylerin öğretmene kavuşacağı umudunu dile getirmiştir. Bu sene içinde 2000 ' i aşkın eğitmen ordusunun hazırlanacağını bildirerek "Henüz köylerine maarif ve mektep girmemiş olan birçok köylerimize Cumhuriyetin vaat ettiği kültür nimetini götürmek gibi en büyük ve en milli bir vazife ve vecibeyi ifa ediyor" demiştir.

Elgün bu konuşmasında özellikle kimsesiz çocuklara da değinmiştir. "Muhterem heyetiniz nasıl milli hazineden bir kuruş üzerinde titriyorsa milli bir servet olan çocuk üzerinde de ayni hassasiyetle ve hatta daha ziyade titremesi lazımdır" demiştir. Annesiz ve babasız çocukların millettin sinesinden başka sığınacak bir yerleri olmadığını hatırlatarak çocuklar için en azından bir yatılı okul açılmasını talep etmiştir. Bu ihtiyacın 1938'de olmazsa en geç 1939 yılı içerisinde giderilmesini istemiştir. Eğitim yolu ile tedbir alınmayacak olursa ileride sıhhi ve adli kanunlarla, ceza evleri ve hastanelerle bedel ödemek zorunda kalınacağını bildirmiştir (TBMM.ZC, 26 Mayıs 1938: 214-216). Bilahare söz olan Maarif Vekili Saffet Arıkan bu talebi değerlendireceğini ve bir çözüm bulmaya çalışacağını ifade etmiştir (TBMM.ZC, 26 Mayıs 1938: 222).

Elgün'ün bu dönemdeki son konuşması İngiltere Hükümeti ile imza edilen kliring ve kredi anlaşmaları hakkındaki kanun münasebeti iledir. O, konuşmasında öncelikle Türk parasının istikrarını, Türk maliye ve iktisadiyatının istiklâlini büyük bir hassasiyetle daima koruyan Hükümete teşekkür etmiştir. İki ülkenin menfaatine olması nedeniyle de İngiltere'ye ve kendi ifadesiyle "Büyük Ingiliz milletine" bu anlaşmayı imzalamakta gösterdiği iyi niyet, samimiyet ve gayretten dolayı teşekkür ederek şunları söylemiştir: "Bence bu mukavelede zikredilen 3 maddeyi ihtiva eden para alışverişi ile malî mukavelelerin fevkinde bir cihet vardır. $O$ da bütün milletlerin 
arasında görmeği candan dilediğim sevgi, itimat ve samimiyettir" demiştir (TBMM.ZC, 28 Haziran 1938, s. 433-434).

\section{Verdiği Kanun Teklifleri ve Önergeler}

Nakiye Elgün 5. dönem milletvekilliği süresince iki kanun teklifine imza vermiştir. Bu kanun tekliflerinin doğrudan düzenleyicisi değildir. İlk kanun teklifi Başbakan İsmet İnönü, ikincisi de Başbakan Celal Bayar tarafından hazırlanmışlardır.

\subsection{Teşkilâtı Esasiye Kanununun $2,44,47,48,49,50,61,74$ ve 75 . maddelerinin değiştirilmesine dair kanun teklifi}

Nakiye Elgün bu kanun teklifini Başbakan İsmet İnönü ile birlikte vermiştir. Teklifte Teşkilatı Esasiye Kanunu'nun 2. maddesinde cumhuriyetin vasıflarına işaret eden bir değişiklik önerilmiştir. Önerilen 2. madde şöyledir: "Türkiye Devleti, cumhuriyetçi, milliyetçi, halkçı, devletçi, lâik ve inkılapçıdır. Resmî dili Türkçedir. Makarrı Ankara şehridir".

Anayasanın 44. maddesine siyasi müsteşarların da meclis üyeleri arasından seçilmesi şartı getirilmiştir. Bu maddedeki değişiklik şöyledir: "Siyasî müsteşarları Başvekil, Meclis azası arasından seçerek Reisicumhurun tasdikine arz eder".

47. madde "Vekillerin ve siyasî müsteşarların vazife ve mesuliyetleri mahsus kanunla tayin olunur" şeklinde önerilmiştir. denilmiştir.

48. maddede "Vekâletlerin ve siyasî müsteşarların adetleri kanunla tayin olunur"

49. madde "Mezun ve herhangi bir sebeple mazur olan bir vekile İcra Vekilleri Heyeti azasindan bir diğeri veya siyasî müsteşarlardan biri muvakkaten niyabet eder. Ancak bir vekil veya bir siyasî müsteşar bir vekaletten fazlasına niyabet edemez ". şekilde değiştirilmiştir.

50. maddede yer alan değişiklik şöyledir: "İcra Vekillerinden veya siyasî müsteşarlardan birinin Divanı âliye şevkine dair Türkiye Büyük Millet Meclisince verilen karar vekâlet ve müsteşarlıktan sukutu dahi mutazammındır".

61. madde şu şekilde değiştirilmiştir. "Vazifelerinden münbais hususatta İcra Vekilleri ile siyasî müsteşarları ve Şurayı Devlet ve Temyiz Mahkemesi rüesası ve azasını ve Cumhuriyet Başmüdde-i umumisini muhakeme etmek üzere bir Divanı Âli teşkil edilir".

74. madde aşağıdaki şekildedir:

"Umumî menfaatler için lüzumu, usulüne göre anlaşılmadıkça ve mahsus kanunları mucibince değer pahası peşin verilmedikçe hiçbir kimsenin malı istimval ve mulkü istimlak olunamaz.

Çiftçiyi toprak sahibi yapmak ve ormanları Devlet tarafindan idare etmek için istimlâk olunacak arazi ve ormanların istimlâk bedelleri ve bu bedellerin tediyesi sureti, mahsus kanunlarla tayin olunur.

Fevkalâde hallerde kanuna göre tahmil olunacak para ve mal ve çalışmaya dair mükellefiyetler müstesna olmak üzere hiçbir kimse hiçbir fedakârlık yapmağa zorlanamaz".

75. madde şu şekilde önerilmiştir:

"Hiçbir kimse mensub olduğu felsefĩ içtihad, din ve mezhebden dolayı muaheze edilemez.

Asayis ve umumî muaşeret adabına ve kanunlar hükümlerine aykır bulunmamak üzere her türlü dinî ayinler yapılması serbesttir" (TBMM ZC, 5 Şubat 1937: S Sayıs1: 89)

Meclis genel kurulunda yapılan görüşmeler neticesinde cumhuriyetin niteliklerini konu alan 2. madde ile birlikte 44, 47, 50, 61, 74 ve 75 . maddelerdeki değişiklikler olduğu gibi kabul 
edilmiştir. 49. maddede önerilen değişiklik de aynen kabul edilmiş ilaveten "Siyasî müsteşarın vekile niyabeti halinde kararnamesi meclise arz olunur" cümlesi eklenmiştir (Resmi Gazete, Say1: 3553: 7659).

\subsection{Teşkilâtı Esasiye Kanununun 44,47,48,49,50 ve 61. maddelerinin değiştirilmesine dair kanun teklifi}

Nakiye Elgün, Başbakan Celal Bayar ile birlikte Teşkilâtı Esasiye Kanununun 44,47,48,49,50 ve 61. maddelerinin değiştirilmesine dair 23 Kasım 1937 tarihinde bir kanun teklifi vermiştir. Söz konusu kanun teklifinin gerekçesinde bir önceki anayasa değişikliği ile teşkil edilen müsteşarlıkların kaldırılması önerilmiştir. Gerekçede 3115 sayılı kanunla anayasanın 44, 47, 49, 50 ve 61. maddeleri ile devlet teşkilatında ihdas edilmiş olan siyasi müsteşarlıkların görevleri, tayinleri ve görevden alınmaları açıklanmıştır. 3117 sayılı kanunun ikinci kısmında da bu müsteşarlıklarla ilgili yapılacak diğer işlemlere yer verilmiştir. Ancak, siyasî müsteşarlıklar oluşturulduktan sonra geçen sekiz aylık süre içerisinde fiiliyatta bu teşkilattan beklenen faydanın elde edilemediği görülmüştür. Müsteşarlıkların bakanlara yardımcı olacağı, onların yükünü ve sorumluluklarını hafifletecekleri beklentisi gerçekleşmemiştir. Zira, bu kişilerin bakanlıklardaki güç ve yetkiye ortak olmaları bakanların otoritelerini zayıflatmıştır. Ayrıca bakan ile siyasî müsteşar arasında görüş farkı ortaya çıkması halinde hükümet otoritesinin zayıflayacağı anlaşılmıştır.

Diğer taraftan iş başına getirilen siyasî müsteşarların tamamı görevlerinden aflarını istemişlerdir. Buna göre devlet teşkilatında zaaf oluşturan söz konusu teşkilatın lüzumsuzluğu net bir şekilde ortaya çıkmıştır. Bütün bu sebeplerden dolayı siyasî müsteşarlıklardan bahseden anayasanın 44, 47, 49, 50 ve 61 . maddelerindeki ilgili hükümlerin çıkarılması önerilmiştir.

Anayasa değişikliğinin ikinci boyutu ise bakanlıkların sayısının ihtiyaca göre belirlenmesi ile ilgilidir. Mevcut hali ile bakanlıkların oluşturulması kanun ile mümkün olabiliyordu. Önerilen 48. madde şöyledir: "Vekaletlerin teşkili tarzı mahsus kanuna tabidir" (TBMM.ZC, 29 Kasım 1937, s. 13). Söz konusu anayasa değişiklikleri 29 Kasım 1937 günü meclis genel kurulunda aynen kabul edilmiştir. 1 Aralık tarihinde de resmi gazetede yayınlanarak yürürlüğe girmiştir (Resmi Gazete, Sayı: 3773: s. 9019). Nakiye Elgün, bu değişiklik teklifinin meclis genel kurulunda oylanması sırasında da kabul oyu vermiştir (TBMM.ZC, 29 Kasım 1937, s. 88)

Elgün 5. dönem milletvekilliği süresince iki de önerge vermiştir. Bu önergelerden ilki 10 Kasım 1937 tarihlidir. Çanakkale Milletvekili Ziya Gevher Etili'nin hazırlamış olduğu önergede Elgünle birlikte 37 milletvekilinin imzası bulunmaktadır. Önergede Cumhurbaşkanı Atatürk'ün meclisin beşinci devresinin üçüncü yılını açarken millete ve hükümete Meclis kürsüsünden verdiği direktifleri ihtiva eden nutku ile bu direktifleri uygulamaya koyan hükümet programının iki kısımdan oluşan bir broşür halinde bastırılarak bütün ülkeye dağıtılmasını teklif edilmiştir. Söz konusu takrir mecliste okunmuş ve ardından oylanarak meclis genel kurulunca kabul edilmiştir (TBMM.ZC, 10 Kasım 1937: 49-50).

İkinci önerge ise Tekirdağ Milletvekili Faik Öztrak ve 9 arkadaşının memurlar hakkındaki kanun teklifi ile ilgilidir. Söz konusu kanun teklifi Dahiliye Encümeni'ne gönderilince Nakiye Elgün'ün de içinde bulunduğu encümen üyeleri bir önerge vererek muhtelit encümen oluşturulmasını teklif etmişlerdir. Önergede şöyle denilmiştir: " Teklif, her encümenin bir içtima senesini işgal edecek derecede mühim esasatı havidir. Elyemv meriyette bulunan memurin kanununun değiştirilmemiş pek az hükmü kalması hasebi ile çok karışık bir hal almasına binaen yerine acilen yeni ve tecrübenin verdiği neticelere uygun bir kanun konması zarurî bulunduğundan evvelki kanunun tanzimi esnasında olduğu gibi, bu teklifin de teşkil olunacak bir Muhtelit encümen tarafindan tetkikinin faydalı olacağının Ulu heyete arzına karar verilmiştir". Meclis genel kurulu bu önergeyi kabul etmiş olup 24 kişiden oluşacak geçici bir encümen kurulmasına karar vermiştir (TBMM.ZC, 11 Mart 1938: 35-36). 


\section{Meclisteki Diğer Faaliyetleri}

Elgün'ün meclisteki faaliyetlerine gelince O, 15 Aralık 1937 tarihi itibarıyla hastalığına binaen 20 gün izin almıştır (TBMM.ZC, 15 Aralık 1937, s. 63). Elgün 5. dönem milletvekilliği süresince toplam 509 oylamaya katılmış ve bunların tamamında evet oyu kullanmıștır. O'nun hiçbir oylamada çekimser kalması ya da ret oyu vermesi söz konusu olmamıştır. O'nun evet oyu kullandığ1 oylamalardan bazıları şunlardır. İsmet İnönü Hükümeti için 7 Mart 1935 tarihinde yapılan güven oylaması (TBMM.ZC, 7 Mart 1935, s. 33). Birinci Celal Bayar Hükümeti için 8 Kasım 1937 tarihinde yapılan güven oylaması (TBMM.ZC, 8 Kasım 1937, s. 41). İkinci Celal Bayar hükümeti için 16 Kasım 1938 tarihinde yapılan güven oylaması (TBMM.ZC, 16 Kasım 1938, s. 56). O'nun oylamalardaki bu tutumu yönetim ile tam bir uyum içerisinde olduğunu göstermektedir. Aslında tek parti yönetiminde farklı bir tavır sergilemesini beklemek de gerçekçi değildir.

Elgün seçim bölgesinin sorunlarıyla da ilgilenmiştir. 1935 yılında hazırladığı raporda bölgedeki sorunların çözümü için önerilerde bulunmuştur. Ulusal kültürün bölgede yayılması için okul sayısının artırılması gerektiğinden bahsetmiştir. Milli birlik ve beraberliğin sağlanmasının temini açısından da okulların önemine işaret etmiştir. Kız çocuklarının okula devamlarının sağlanabilmesi için bölgede devletin özel çaba sarf etmesi gerektiği dile getirmiştir. Bölgedeki Kürt nüfusun sorun haline dönüşmemesi için acilen ilgilenilmesi gerektiğine işaret etmiştir. Bir an evvel Toprak Kanunu'nun çıkarılmasının halkın yararına olacağını belirtmiştir (Duroğlu, 2007, s. 91).

\section{Encümen Faaliyetleri}

Nakiye Elgün 5. dönemin birinci yasama y1lında Dahiliye Encümeni'nde görev yapmıştır (TBMM ZC, 7 Mart 1935: 25).2.y1l (TBMM.ZC, 6 Kasım 1935: 8), ve 3.y1l da aynı encümene seçilmiştir (TBMM.ZC, 9.Kasım 1936: 12). 4. yıl 279 oyla (TBMM.ZC, 5.Kasım 1937: 14), 5. y1l 250 oyla Dahiliye Encümeni'ne ayrılmıştır (TBMM.ZC, 7.Kasım 1938, s. 12). Elgün bu encümene gönderilen kanun teklifleri için mazbata hazırlanmasına katkı sağlamıştır.

\subsection{0 sayılı Dahiliye Memurları kanununun 2. maddesini değiştiren 2429 sayılı kanunun 1. maddesinin Değiştirilmesi Hakkındaki Kanun Layihası için hazırlanan mazbata.}

Söz konusu kanun teklifi İçişleri Bakanlığı tarafından hazırlanmış olup Başbakanın imzası ile 8 Mayıs 1935 tarihinde meclis başkanlığına arz edilmiştir. Meclis başkanlığı da ilgisi dolayısıyla görüş almak amacıyla Dahiliye Encümeni'ne sevk etmiştir. Encümen İçişleri Bakanlığı Vilayetler idaresi Genel Müdürü de hazır bulunduğu toplantıda konuyu ele almıştır. Nihayetinde 29 Mayıs 1935 tarihli bir mazbata hazırlamıştır. Buna göre mevcut kanunda Mülkiye Mektebi ve Hukuk Fakültesi mezunlarının stajyerlik anlamındaki namzetliklerini birinci sınıf nahiye müdürlüklerinde veya bu derecedeki memurluklarda geçirmeleri gerekmekteydi. Oysa buralarda yeterince boş kadro bulunmaması yüzünden bazen mezunların istihdamları mümkün olamamaktadır. Bu durum mağduriyetlerine yol açtığından mağduriyeti giderici düzenlemelerin yapılması kabul edilmiştir (TBMM.ZC, 3 Haziran 1935, s. 143).

\subsection{Ekim 1926 tarihinden evvel mevcut olan Vakıflar Hakkındaki Kanun Layihası hakkında mazbata}

Vakıflar Genel Müdürlüğü tarafından hazırlanan kanun teklifi 12 Haziran 1932 tarihinde Başbakanın imzası ile Meclis Başkanlığına sunulmuştur. Meclis Başkanlığı teklifi Dahiliye Encümenine de havale etmiştir. Encümen Vakıflar Genel Müdür Vekili ve Başbakanlık müsteşarı da hazır bulunduğu halde kanun teklifini değerlendirmiştir. 6 Mayıs 1935 tarihinde de mazbatasını hazırlamıştır.

Mazbatada öncelikle vakıf malların idaresi ve denetlenmesi usulleri hakkında zamanın ihtiyacına uygun düzenlemelerin gerekliliğine işaret edilmiştir. Vakıflar Genel Müdürlügünde en 
geniş yetkiye sahip olacak idare meclisine bir üye daha ilave edilmesi kabul edilmiştir. Ayrıca genel müdürün de oy sahibi olarak İdare meclisine katılması uygun bulunmuştur. Yine idare meclisinin görevleri arasına nizamname layihalarının hazırlanması ve incelenmesi eklenmiştir. Vakıf binalarının sigortası için ayrılacak para miktarı yeterli ise mülhak vakıfların binalarının da sigorta ettirilmesi önerilmiştir.

Denetleme işinin kolaylaşmasını temin için mütevellilerin illerdeki evkaf dairelerine bir bütçe vermesi istenmiştir. Azli katileşen mütevelli başka bir vakfın da mütevellisi ise oradaki görevinden de azledilmiş sayılması ve bir daha mütevelli olamaması ilkesi getirilmiştir. Evkaf idaresince vakıf oldukları tespit edilip o şekilde tapu kaydı yaptırılması için verilen beş senelik müddet fazla görülerek iki seneye indirilmiştir. Bu hususların tamamı yasaya eklenmiştir (TBMM ZC, 3 Haziran 1935, s. 124-2).

\subsection{Polisin vazife ve salahiyeti kanununun 5. maddesinin A fikrasının değiştirilmesine dair kanun layihası hakkında mazbata}

Dahiliye Vekaleti tarafından hazırlanan kanun teklifi 4 Nisan 1935 tarihinde başbakanın imzası ile Meclis Başkanlığına gönderilmiştir. Meclis başkanlığı teklifi ilgisi nedeni ile Dahiliye Encümeni'ne sevk etmiştir. Encümen Emniyet İşleri Genel Müdür yardımcısının da hazır bulunduğu toplantıda kanun teklifini incelemiş ve 27 Nisan 1935 tarihli bir mazbata hazırlamıştır. Mevcut yasada hırsızlık, dolandırıcılık gibi mal aleyhine işlenen suçlarda zanlıların ve mahkumlarının parmak izlerinin alınması yalnız ağır cezayı gerektiren hallerde söz konusuydu. Bu uygulama suçluların takibini zorlaştırdığından yeni düzenlemede parmak izi alınmasına izin verilmiştir (TBMM ZC, 5 Haziran 1935, s. 151).

\subsection{Mıntaka sanat mekteplerinin Maarif vekaleti tarafından idaresi hakkındaki kanun layihası için mazbata}

Milli Eğitim Bakanlığı'nca hazırlanan kanun teklifi 29 Nisan 1935 tarihinde Başbakan İsmet İnönü imzası ile meclis başkanlığına havale edilmiştir. Meclis başkanlığg görüş sormak amacıyla teklifi encümene sevk etmiştir. Dahiliye Encümeni içişleri ve milli eğitim bakanlarının da bulunduğu bir toplantıda kanun tasasını tartışmıştır. Bilahare 25 Mayıs 1935 tarihli bir mazbata düzenlemiştir. Encümen yıllardır yaşanan tecrübelerin neticesinde bu mekteplerin Maarif Vekilliği'nce idare olunması kararına varmıştır. Böylece vilayetlerin de taşıyamadıkları bir yükten kurtarılmış olacağı belirtilmiştir (TBMM.ZC, 7 Haziran 1935, s. 153).

\subsection{Kanunla verilen izinler üzerine yapılan kefaletlerin nasıl yerine getirileceği hakkında kanun lâyihası hakkında mazbata}

Kanun teklifi Maliye Bakanlığı tarafindan hazırlanarak 7 Haziran 1935 tarihinde Başbakan İsmet İnönü imzasıyla meclis başkanlığına havale edilmiştir. Encümen Maliye Bakanı huzurunda teklifi incelemiştir. 11 Haziran 1935 tarihli mazbatada kanun teklifi yerinde bulunarak aynen kabul edilmiştir (TBMM ZC, 14 Haziran 1935, s. 203).

6.6. Tabiiyet muamelelerinden alınacak harçlara dair kanuna müzeyyel 1942 sayılı kanunun 2. maddesinde yazılı müddetin 3 yıl daha uzatılması hakkında kanun lâyihası mazbatası

Adı geçen kanun Dahiliye Vekaleti tarafından hazırlanmıştır. Başbakan imzası ile 8 Nisan 1935 tarihinde meclis başkanlığına gönderilmiştir. Tezkere İçişleri Bakanlığı tabiiyet müdürünün de hazır bulunduğu bir toplantıda değerlendirilerek 25 Mayıs 1935 tarihli mazbata hazırlanmıştır. Buna göre tabiiyet muamelatından alınacak harçların fakirliğini ispat eden muhacir ve mültecilerden 3 yıl daha alınmaması teklifi uygun bulunmuştur. İşlemlerin iki sene içinde neticelendirilmesi için kanuna bir fikra ilavesi gerekmiştir. Bu hususta ilgili memurlara yükümlülük verilerek işlemleri tamamlamaları mecburiyet getirilmiştir (TBMM.ZC, 14 Ekim 1935, s. 242). 
6.7. Yabancıların Türk vatandaşlı̆̆ı mevzubahis olmayan tabiiyet tetkikleri üzerine verilen kararlar aleyhine şurayı devlete müracaat edilip edilemeyeceğine dair başbakanlık tezkeresi için hazırlanan mazbata

Bu hususta Dahiliye Vekaleti tarafindan hazırlanan tezkere 9 Haziran 1934 tarihinde Başbakan İsmet İnönü imzası ile meclis başkanlığına havale edilmiştir. Meclis Başkanlığı teklifi ilgisi nedeni ile Dahiliye Encümenine de sevk etmiştir. Encümen İçişleri Bakanlığ Tabiiyet Müdürü Muzaffer Akalın, Şurayı Devlet Tanzimat Dairesi Başkanı İsmail Hakkı Özer ve Dışş̧leri Bakanlığı Hukuk Müşaviri Ziya Kızıltan'ın da hazır bulundukları bir toplantıda konuyu inceleyerek 25 Mayıs 1935 tarihli bir mazbata hazırlamıştır. Buna göre bu gibi işlerin şurayı devlet kanununun 19. maddesi çerçevesi dışında bulunduğuna ve ayrıca bir tefsire gerek olmadığ 1 kararına varılmıştır (TBMM.ZC, 23 Aralık 1935, s. 55).

6.8. Ecnebilerin seyahat ve ikametleri hakkındaki 2 Mart 1331 tarihli muvakkat kanuna müzeyyel 935 sayılı kanunun 1. maddesinin değiştirilmesine ve bu kanuna bazı maddeler eklenmesine dair kanun layihası hakkında mazbata

Maliye Bakanlığı tarafından hazırlanan kanun teklifi 20 Haziran 1936 tarihinde Başbakan İnönü imzası ile Türkiye Büyük Millet Meclisi Başkanlığına havale edilmiştir. Meclis Başkanlığı da teklifi ilgisi nedeni ile Dahiliye Encümeni'ne göndermiştir. Encümen Emniyet İşleri Umum Müdürü'nün de hazır bulunduğu bir toplantıda kanun teklifini değerlendirerek 23 Aralık 1936 tarihli bir mazbata hazırlamıştır. Buna göre yabancılardan alınan ikamet ücretinin artırılması ve yabancıların daima gözetim altında bulundurulması uygun bulunmuştur. 2 Mart 1915 tarihli muvakkat kanunun da kaldırılması önerilmiştir. Ancak Türkiye'ye okumaya gelecek yabancı öğrenciler ile yabancı mütehassıslardan ve uzmanlardan harç alınmaması istenmiştir. Yine ortaya çıkabilecek bazı özel hallerde de hükümete yetki verilmesi uygun bulunmuştur (TBMM.ZC, 16 Nisan 1937, s. 137).

6.9. Ortaokul öğretmenleri yetiştirmek maksadı ile Gazi Terbiye Enstitüsü'nde açılan kursa devam eden öğretmen okulu mezunları hakkında kanun layihası hakkında mazbata

Maarif Vekaleti tarafından hazırlanan kanun teklifi 5 Haziran 1937 günü Başbakan İnönü imzası ile Meclis Başkanlığı'na gönderilmiştir. Bilahare layiha ilgisine binaen Dahiliye Encümeni'ne sevk edilmiştir. Dahiliye Encümeni Maarif Vekaleti temsilcisinin de hazır bulunduğu bir toplantıda konuyu değerlendirmiştir. Toplantıda Maarif encümeninin mazbatası da okunmuş ve incelenmiştir. Nihayetinde 7 Ocak 1938 tarihli Dahiliye Encümeni mazbatası hazırlanmıştır. Buna göre Ortaokullardaki öğretmen kadrolarındaki boşluğun biran evvel doldurulabilmesi için kanun teklifinin aynen kabulü uygun görülmüştür (TBMM.ZC, 14 Mart 1938, s. 104).

\subsection{Türk gayri mübadillerine tahsis edilen malların vergileri hakkında kanun layihası için hazırlanan mazbata}

Maliye Vekaletince hazırlanan kanun tasarısı Başbakan İnönü imzası ile 1 Haziran 1937 tarihinde Meclis Başkanlığına havale edilmiştir. Meclis Başkanlığı da tasarıyı ilgisi nedeni ile Dahiliye Encümeni'ne sevk etmiştir. Encümen Dahiliye Vekaleti siyasi-müsteşarının da hazır bulunduğu bir toplantıda kanun teklifini görüşmüş ve 7 Haziran 1937 tarihli bir mazbata hazırlamıştır. Buna göre öncelikle gayri mübadillere tahsis edilen malların birikmiş vergilerini, müşterilerinin ödemeğe mecbur olmasının satışa engel olduğu üzerinde durulmuştur. Hak sahiplerine verilmek üzere devlete intikal eden bu malların eski sahiplerinden vergisi alınmayacağına göre bugüne kadar tahakkuk etmiş vergilerin silinmesi önerilmiştir. Encümen ayrıca söz konusu vergilerin bakayasından mahalli idarelerin sorumlu tutulmamasını, malların gelirlerini şimdiye kadar tahsil etmiş olan hazinenin mahalli idarelere ödeme yapmasını da istemiştir (TBMM.ZC, 18 Nisan 1938, s. 147). 
6.11. Maarif daireleri mümeyyiz, başkatip ve katipleri ile debboy, levazım, sevk memurları ve levazım katiplerinin hususi idarelere verilmesi ve ilk tedrisat müfettişlerinin umumi muvazeneye alınması hakkındaki kanun teklifi

Söz konusu kanun teklifi Maarif Vekaleti tarafından hazırlanmış ve 18 Mayıs 1937 tarihli Bakanlar Kurulu toplantısında kabul edilmiştir. Bilahare teklif 21 Mayıs 1937 tarihinde Başbakan imzası ile meclis başkanlığına gönderilmiştir. Meclis başkanlığı ilgisi nedeni ile teklifi Dahiliye Encümeni'ne de göndermiştir. Ancak layihanın müzakeresine başlanacağı sırada Maarif vekili bu hususta başka bir tedbir düşünüleceğini beyan edince müzakere tehir edilmiştir. Bu doğrultuda 30 Mayıs 1938 tarihinde meclis genel kurulunda kabul edilmiş olan 3407 sayılı kanunla mesele halledilmiştir. Dolayısıyla söz konusu layihanın müzakeresine lüzum kalmamıştır. Bilahare meclis genel kurulunda bu mazbata oylanarak kabul edilmiştir (TBMM ZC, 13 Haziran 1938, s. 104-105).

6.12. Ulusal bayram ve genel tatiller hakkındaki 2739 sayılı kanunun 2 . maddesine bir fikra ve mezkûr kanuna bir madde ilavesine dair kanun layihası hakkında mazbata

Dahiliye vekilliğince hazırlanan kanun teklifi 1 Haziran 1938 tarihinde Başbakan Celal Bayar imzası ile meclis başkanlığına gönderilmiştir. Meclis Başkanlığı teklifi ilgisi nedeni ile Dahiliye Encümeni'ne havale etmiştir. Encümen 6 Haziran 1938 tarihli toplantısında layihayı incelemiştir. 8 Haziran 1938 tarihinde de mazbatasını hazırlamıştır. Mazbatada hükümetin layihada belirttiği görüşler uygun bulunmuş, esasla alakası olmayan küçük bazı değişiklikler yapmıştır (TBMM.ZC, 13 Haziran 1938: S Sayısı 248).

\subsection{Mahrukat kanunu lâyihası hakkında mazbata}

İktisat vekaleti tarafından hazırlanan kanun teklifi 10 Mayıs 1937 tarihinde Başbakan Vekili Dr. Reşit Saydam imzası ile meclis başkanlığına gönderilmiştir. Meclis başkanlığı alakası nedeni ile kanun teklifini Dahiliye Encümeni'ne havale etmiştir. Dahiliye encümeni İktisat ve Nafia vekaletleri temsilcilerinin de hazır bulundukları toplantı sonunda 25 Mayıs 1938 tarihli bir mazbata hazırlamıştır.

Buna göre encümen maden kömürü kullanılmasını desteklemekle beraber ülkenin gerçeklerine de dikkati çekmiştir. Kömürde üretim vasıtalarının gelişmemiş olması ve nakliye ücretleri gibi sebeplerin fiyatı artırdığını hatırlatmıştır. Bu şartlarda memleketin pek çok yerinde kömür yakı1masının mümkün olamayacağı, halkın ucuz yakıt olan oduna yöneleceği belirtilmiştir. $\mathrm{Bu}$ durumunda ormanların tahribine yol açtığını kabul etmiştir. Encümen ülke şartlarının dikkate alınarak kanunun tatbikatında esneklik önermiştir (TBMM.ZC, 13 Haziran 1938, s. 250).

6.14. İdarei umumiyei vilayat kanununun muaddel 84. maddesinin değiştirilmesine dair kanun lâyihası hakkında mazbata

Dahiliye vekilliğince hazırlanan kanun teklifi 8 Haziran 1938 tarihinde Başbakan Celal Bayar imzası ile meclis başkanlığına gönderilmiştir. Meclis başkanlığı ilgisi nedeni ile teklifi layiha encümenine havale etmiştir. Encümen dahiliye vekaleti mahalli idareler umum müdürünün de hazır bulunduğu bir toplantıda teklifi incelemiştir. Nihayetinde 16 Haziran 1938 tarihli bir mazbata hazırlanmıştır. Buna göre vilayet özel idareleri bütçelerinin düzenlenmesi esnasında bazı vilayetlerce gelir arttırıcı haklı sebepler olmamasına rağmen fazla tahminlere dayanan bütçeler yapılması eleştirilmiştir. Bu vilayetlerin bir takım lüzumsuz masraflarını bu suretle karşılamak istediklerine dikkat çekilmiştir. Bütçe hazırlanırken esas olanın bir önceki yılın geliri olduğu hatırlatılmıştır. Dolayısıyla kanun teklifi küçük değişikliklerle encümen tarafından onaylanmıştır (TBMM.ZC, 22 Haziran 1938, s. 268).

\subsection{Ekalliyetlere ait dini müesseselerin idaresi hakkında kanun layihası hakkında mazbata}

Kanun teklifi Dahiliye Vekaleti tarafından hazırlanmıș olup 5 Haziran 1933 tarihinde Başbakan İsmet İnönü imzası ile meclis başkanlığına gönderilmiştir. Meclis Başkanlığı teklifi 
alakası nedeniyle Dahiliye Encümeni'ne havale etmiştir. Encümen dahiliye, adliye, hariciye, sshhat ve içtimai muavenet vekilleri ve mümessilleri huzurunda kanun teklifini değerlendirmiştir. Nihayetinde 28 Nisan 1937 tarihli bir mazbata hazırlamıştır. Mazbatada yardımlaşmanın önemine işaret edilmiş, cemiyetlerin teşvik edilmesi gerektiği üzerinde durulmuştur. Buna rağmen cemiyetlerin zararlı ve tehlikeli olabilecekleri de hatırlatılmıştır. Hükümetin biri yedi ve öbürü dört yıl önce gönderdiği iki layiha değerlendirerek yeni bir kanun teklifi hazırlanmıştır (TBMM.ZC, 28 Haziran 1938, s. 303).

\subsection{Basın birliği kanunu layihası hakkında mazbata}

Dahiliye vekaletince hazırlanan kanun teklifi 13 Mayıs 1937 tarihinde Başbakanlık tarafından meclis başkanlığına gönderilmiştir. Meclis Başkanlığı da ilgisi nedeni ile Dahiliye Encümeni'ne sevk etmiştir. Encümen Dahiliye vekaleti siyasi müsteşarının da hazır bulunduğu bir toplantıda teklifi incelemiş ve 5 Haziran 1937 tarihli bir mazbata hazırlamıştır. Mazbatada nizamname ile halledilebilecek teferruat içeren bazı hükümlerin kanun metninden çıkarılması istenmiştir. Kanunun uygulanmasını gösteren nizamnameye bu madde ve metinlerin eklenmesi önerilmiştir. Ayrıca kanun maddelerinde bazı ifade değişiklikleri yapılmıştır. İlaveten kanuna yabancı basın temsilcileri hakkında bir madde eklenmiştir (TBMM.ZC, 28 Haziran 1938, s. 304).

\subsection{Pasaport kanunu lâyihası hakkında mazbata}

Dahiliye vekaletince hazırlanan kanun teklifi 16 Mayıs 1938 tarihinde başbakanlık tarafından meclis başkanlığına gönderilmiştir. Meclis başkanlığı da ilgisi nedeni ile Dahiliye Encümeni'ne sevk etmiştir. Encümen, Dahiliye ve Maliye vekaletlerinin temsilcilerinin de hazır bulunduğu bir toplantıda teklifi incelemiş ve 8 Haziran 1938 tarihli bir mazbata hazırlamıştır. Buna göre encümen 20 Kasım 1918 tarihli pasaport kanununun bu günkü ihtiyaçlara cevap vermediği, cumhuriyet idaresine yabancı birçok tabirlerle de dolu olduğu gerekçeleriyle değiştirilmesini doğru bulmuştur. Teklifi esas itibarıyla uygun bulmakla beraber bazı değişiklikler önermiştir. Pasaportların; diplomatik, hususi, hizmete mahsus, adi olmak üzere tasnifini doğru bulmamıştır. Siyasi şahsiyetlere ve siyasi bir vazife ile görevlendirilmiş milletvekillerine pasaport verilmesi lüzumuna değinmiştir. Yurt dışına çıkması gereken hastalara refakat edecek kişilere de pasaport verilmesi gerekliliğine işaret etmiştir. Döviz sıkıntısı yüzünden insani gerekçelerin görmezden gelinemeyeceğini hatırlatmıştır. Döviz çıkışını engellemek için hükümetin elinde başka yetkiler bulunduğu belirtilmiştir. Encümen kanun maddelerinde söz konusu sakıncaları giderici değişiklikler önermiştir (TBMM.ZC, 28 Haziran 1938, s. 310).

\subsection{Matbualara eşya sarılmaması hakkında kanun layihası hakkında mazbata}

Dahiliye vekaletince hazırlanan kanun teklifi 26 Nisan 1938 tarihinde Başbakan Celal Bayar İmzası ile meclis başkanlığına gönderilmiştir. Meclis başkanlığı da ilgisi nedeni ile Dahiliye Encümeni'ne sevk etmiştir. Encümen, Dahiliye ve Sihhat ve İçtimai Muavenet Vekaletleri mümessillerinin hazır bulunduğu bir toplantıda teklifi incelemiş ve 14 Haziran 1938 tarihli bir mazbata hazırlamıştır. Bu mazbatada öncelikle basılı kağıtlara sağlık nedeni ile eşya sarılmamasının gerekliliğine işaret edilmiştir. Bununla birlikte satılmayan önemli miktarda gazete nüshasının kese kağıdı olarak kullanıldığına dikkat çekilmiştir. Ancak yine de bu hususta yasak getirilmesinin gazete sahiplerini zarara uğratacağına dikkat çekilmiştir. Yasağın kitap ve defterlerle sınırlandırılması talep edilmiştir (TBMM.ZC, 28 Haziran 1938, s. 322).

6.19. Af kanunu layihası ile heyeti mahsusalarca aleyhlerine verilip kendilerine teblĭg edilmeyen kararlara karşı alakalıların itiraz edebilmeleri hakkında kanun layihası hakkında mazbata

Milli Müdafaa Vekaletince hazırlanan kanun teklifi 2 Aralık 1937 tarihinde Başbakan Celal Bayar İmzası ile meclis başkanlığına gönderilmiştir. Meclis başkanlığı da ilgisi nedeni ile Dahiliye Encümeni'ne sevk etmiştir. Encümen, Milli Müdafaa Vekaleti temsilcisinin de hazır bulunduğu bir toplantıda teklifi incelemiş ve 3 Mart 1938 tarihli bir mazbata hazırlamıştır. Bu 
mazbatada aleyhlerine verilen kararların kendilerine tebliğ olunamamasından dolayı itiraz edememiş olanların mahrumiyetlerinin giderilmesi adalet anlayışına uygun bulunmuştur. Encümen ayrıca kendilerine tebliğ edilen kararlara herhangi mücbir bir sebep yüzünden itiraz edememiş olanlara da müracaat hakkı verilmesini istemiştir (TBMM.ZC, 29 Haziran 1938, s. 309).

6.20. Umumi, mülhak ve hususi bütçelerle idare edilen daireler arasındaki ihtilafların tahkim yolu ile halli hakkında kanun layihası hakkında mazbata

Adliye Vekâletince hazırlanan kanun teklifi 30 Mayıs 1938 tarihinde Başbakan Celal Bayar İmzası ile meclis başkanlığına gönderilmiştir. Meclis başkanlığı da ilgisi nedeni ile Dahiliye Encümeni'ne sevk etmiştir. Encümen, adliye vekilinin ve dahiliye vekaleti hukuk müşavirinin de hazır bulundukları 7 Haziran 1938 tarihindeki toplantıda layihayı incelemiştir. Nihayetinde 3 Mart 1938 tarihli bir mazbata hazırlamıştır.

Bu mazbatada umumi, mülhak veya hususi bütçelerle idare edilen devlet dairelerinin birbirleri ile veya belediyelerle olan ihtilaflarını hakem yoluyla seri bir şekilde çözmeleri önerilmiştir. Hakem olarak temyiz mahkemesi, şurayı devlet ya da Sayıştay başkanlarından birinin tayin edilmesi uygun görülmüştür. Böylece mahkemelerin bir kısım meşguliyetlerinden kurtarılacağı belirtilmiştir. Hakemlerin kararına karşı mahkemelere müracaat edilemeyeceğine hükmedilmiştir. 4. maddede yazılı merciden verilen karara itiraz müddeti altmış güne çıkarılmıştır. Kanunun yürürlüğe girme tarihi 1 Eylül 1938 olarak kabul edilmiştir (TBMM.ZC, 29 Haziran 1938, s. 334).

\subsection{Emniyet teşkilatı kanununa ek kanun layihası hakkında mazbata}

Dahiliye Vekâletince hazırlanan kanun teklifi 28 Haziran 1938 tarihinde Başbakan Celal Bayar İmzası ile meclis başkanlığına gönderilmiştir. Meclis Başkanlığı da ilgisi nedeni ile Dahiliye Encümeni'ne sevk etmiştir. Encümen layiha hakkındaki incelemelerini tamamlayarak 28 Haziran 1938 tarihli bir mazbata hazırlamıştır. Buna göre layiha uygun görülmüş ve aynen kabul edilmiştir (TBMM.ZC, 29 Haziran 1938, s. 336).

6.22. Mübadil gayri mübadil, muhacir ve saireye kanunlarına tevfikan teffiz veya adiyen tahsis olunan gayrimenkul emvalin tapuya raptına dair olan 1331 sayılı kanunun 9ncu maddesinin tefsiri hakkında Başvekâlet tezkeresi hakkında mazbata

Maliye Vekâletince Temlik kanununun 9. maddesinin tefsiri hakkındaki tezkere 23 Mayıs 1938 tarihinde Başbakan Celal Bayar İmzası ile meclis başkanlığına gönderilmiştir. Meclis Başkanlığı da ilgisi nedeni ile tezkereyi Dahiliye Encümeni'ne sevk etmiştir. Encümen Maliye ve Sihhat ve içtimai muavenet vekaletleri mümessillerinin de hazır bulundukları 1 Haziran 1938 tarihindeki toplantıda konuyu ele almıştır. Nihayetinde 8 Haziran 1938 tarihli bir mazbata hazırlamıştır.

Buna göre maliye vekaleti ile sıhhat ve içtimai muavenet vekaleti arasında yorum fark1 oluşmuştur. Sihhat ve içtimai muavenet vekilliği mübadillere istihkakları mukabilinde 488 sayılı kanun mucibince verilen gayrimenkuller üzerinde sahiplerinin kayıtsız ve şartsız tasarruf hakkı mevcut olduğunu ve bu mallar üzerindeki hazine hakkının 1331 sayılı kanunun 9. maddesinde gösterilen yetkilere dayandığını belirtmiştir. Sağlık bakanlığı ise bu maddede tespit edilen beş sene müddet geçtiği için haksız mal tasarruf edenler hakkında bugün bir şey yapılmasına imkan olmadığını ileri sürmüştür. Maliye Vekaleti de buna itiraz etmiştir. Buna karşılık Dahiliye Encümeni'nin yorumu şu şekilde olmuştur: "1331 sayılı kanunun neşri tarihinde Türk kanunu medenisi hükümleri mevcut olmasına rağmen mezkûr kanunun 9. maddesi ile başka bir müruru zaman haddi kabul edilmesine ve 840 sayll kararla da bu müddetin müruru zaman müddeti olduğu tasrih edildiği gibi bu kabil meselelerin ortadan kaldırılması arzusu gösterilmiş olmasına ve 28 Mart 1931 tarih ve 1771 sayll kanunun dahi ayni maksatla tedvin edilmesine binaen encümenimiz 1331 sayılı kanunun 9. maddesini başka suretle tefsire mütehammil bulmamıştır" (TBMM.ZC, 19 Aralık 1938, s. 18). 


\subsection{Devlet şurası Reisliği ile beşinci daire Reisliği ve on azalık için seçim yapılması hakkında Başvekâlet tezkeresi hakkında mazbata}

Şurayı Devlet Başkanı Reşad Mimaroğlu'nun emeklilik dilekçesi vermesi dolayısıyla yeni başkanın seçilmesi gerekiyordu. Ayrıca 3546 sayılı kanunla yeniden teşkili icap eden şurayı devlet 5. dairesi başkanı ile kadroya ilave edilen 8 ve muhtelif tarihlerde açılan 2 olmak üzere toplam 10 üyelik için adaylar listesini içeren tezkere Başbakan Celal Bayar imzası 4 Ocak 1939 tarihinde meclis başkanlığına gönderilmiştir. Hükümetin tezkeresinde şurayı devlet başkanlığ 1 için 5 aday, 5. daire başkanlığ için 5 ve şurayı devlet üyeliği için de 55 aday mevcut idi. Meclis Başkanlığı konuyu şurayı devlet kanununun 3.maddesi gereğince Adliye ve Dahiliye encümenlerinden oluşan muhtelit encümene havale etmiştir. Dahiliye encümeni adına Muhtelit Encümen'de görevlendirilenler arasında Nakiye Elgün de bulunmaktaydı. Muhtelit encümen çalışmalarını tamamlayarak 18 Ocak 1939 tarihli mazbata hazırlamıştır. Bu mazbatada hükümet tarafından gönderilen listeden şurayı devlet başkanlığına 3, 5. Daire Başkanlığına 3 ve şurayı devlet üyeliğine de 30 aday gösterilmiştir (TBMM ZC, 20 Ocak 1939, s. 50'ye ek).

6.24. Dahiliye vekaleti merkez teşkilat ve vazifeleri hakkındaki 1624 sayılı kanunla bu kanunun bazı hükümlerini değiştiren 3406 sayılı kanunda değişiklik yapılmasına dair kanun layihası hakkında mazbata

Dahiliye Vekâletince hazırlanan kanun teklifi 9 Ocak 1939 tarihinde Başbakan Celal Bayar İmzası ile meclis başkanlığına gönderilmiştir. Meclis Başkanlığı da ilgisi nedeni ile teklifi Dahiliye Encümeni'ne sevk etmiştir. Encümen, Dahiliye vekilinin hazır bulunduğu bir toplantıda layihayı incelemiştir. Nihayetinde 17 Ocak 1939 tarihli bir mazbata hazırlamıştır. Buna göre vekalet kadrosuna bir müsteşar ilave edilmesi uygun görülmüştür. Bunun dışında kanun metni genel hatları ile kabul edilmiştir. Metinde küçük kelime değişiklikleri yapılmıştır (TBMM ZC, 23 Ocak 1939, s. 57).

\subsection{5 mali yılı sonuna kadar olan arazi vergisi bakayasının munzam kesir ve cezaları ile birlikte affına dair kanun layihası hakkında mazbata}

Dahiliye ve Maliye vekaletleri tarafindan hazırlanan kanun teklifi 16 Ocak 1939 tarihinde Başbakan Celal Bayar İmzası ile meclis başkanlığına gönderilmiştir. Meclis Başkanlığı da ilgisi nedeni ile Dahiliye Encümeni'ne sevk etmiştir. Encümen Dahiliye vekili ve Maliye vekaleti varidat umum müdürünün de hazır bulundukları bir toplantıda layihayı incelemiştir. Nihayetinde 20 Ocak 1939 tarihli bir mazbata hazırlamıştır.

Buna göre encümen kanun teklifini uygun görmüştür. Muafiyet müddetinin, 1935 mali yılı sonu ile sınırlandırılmasını önermiştir. Kanun teklifinin 1,2 ve 3. maddeleri ise aynen kabul edilmiştir. Kanunun adı üzerinde ise bir kısaltma yapılması önerilmiştir (TBMM ZC, 26 Ocak 1939, s. 62).

6.26. İdarei umumiyei vilayat kanununun bazı maddelerini değiştiren 2630 sayılı kanunun 2. maddesinin tadili hakkında kanun layihası mazbatası

Dahiliye vekaleti tarafından hazırlanan kanun teklifi 20 Ocak 1939 tarihinde Başbakan Celal Bayar İmzası ile meclis başkanlığına gönderilmiştir. Meclis Başkanlığı da ilgisi nedeni ile Dahiliye Encümeni'ne sevk etmiştir. Encümen teklif üzerindeki incelemelerini tamamlayarak 23 Ocak 1939 tarihli bir mazbata hazırlamıştır.

Mazbatada mevcut kanunların vilayet umumi meclisleri üyelerinin seçim tarihi ve hizmet süreleri hakkındaki hükümlerin bu günkü şartları karşılayabilecek durumda olmadığını belirtmiştir. Sonradan teşkil edilmiş bulunan bazı vilayetlerin umumi meclislerinin seçim sürelerinin diğer vilayetler ile birleştirmesi uygun bulunarak kanuna geçici bir madde ilave edilmiştir. Encümen kanunun yayınlanmasından evvelki zamanı kapsamasını eleştirmiş yayım tarihinden itibaren geçerli olacağı şeklinde bir düzeltme daha yapmıştır (TBMM.ZC, 26 Ocak 1939, s. 67). 


\subsection{Arazi vergisi hakkındaki 1833 sayılı kanunun bazı hükümlerinin değiştirilmesi hakkında kanun layihası hakkında mazbata}

Bakanlar kurulu tarafından hazırlanan kanun teklifi 7 Mayıs 1938 tarihinde Başbakan Celal Bayar İmzası ile meclis başkanlığına gönderilmiştir. Meclis Başkanlığı da ilgisi nedeni ile Dahiliye Encümeni'ne sevk etmiştir. Encümen Maliye ve Dahiliye vekaletlerinden gönderilen memurlar da hazır olduğu halde teklif üzerindeki incelemelerini tamamlayarak 10 Ocak 1939 tarihli bir mazbata hazırlamıştır.

Buna göre arazi vergisinin devlet gelirleri arasından alınarak vilayet hususi idarelerine devredilmesi 1833 numaralı arazi vergisi kanununda değişiklik yapılmasını zorunlu kılmıştır. Bu yüzde değişiklik teklifi encümen tarafından uygun görülmüştür. Mevcut arazi kanunu hükümetçe bir bölgeye iskan edilen muhacir ve aşiretleri üç sene müddetle arazi vergisinden muaf tutmuştu. İskan kanununun 37. maddesi bu muafiyeti genişletmişti. Encümen bu iki kanun arasındaki farkl1lı̆̆ın tarih belirtilerek çözümlenmesini istemiştir (TBMM.ZC, 26 Ocak 1939, s. 70).

\subsection{Belediye kanununa ek kanun lâyihası hakkında Muhtelit encümen mazbatası}

1580 sayılı Belediye Kanunu'na ek olarak Maliye Bakanlığı'nca bir kanun teklifi hazırlanmıştır. Söz konusu teklif başbakanın imzasıyla 16 Aralık 1934 tarihinde meclis başkanlığına gönderilmiştir. Meclis Başkanlığı teklifi Nakiye Elgün'ün de üyesi bulunduğu muvakkat encümene havale edilmiştir. Encümen incelemelerini tamamlayarak 6 Haziran 1935 tarihinde bir mazbata hazırlamıştır. Buna göre encümen bazı maddelerde değişiklik önermiştir. Çok parayı gerektiren hizmetlerin nüfusu 10 binden fazla olan belediyelerce yapılmasını önermiştir. Yine mali güce dayanan elektrik ve mezbaha tesisatının vücuda getirilmesinin belediyelerin kararına bırakılması teklif edilmiştir. Belediye imar heyetinin fen ve yazı işlerinin mütehassıs memur ve mimarlar kadrosunun genişletilmesi önerilmiştir (TBMM.ZC, 7 Haziran 1935, s. 167).

\subsection{Arazi ve bina vergilerinin vilayet hususi idarelerine terki hakkında kanun layihası ve Dahiliye ve Maliye encümenlerinden mürekkep muhtelit encümen mazbatası}

Maliye Bakanlığı tarafından hazırlanan kanun teklifi 31 Ekim 1935 tarihinde Başbakan İsmet İnönü imzası ile meclis başkanlığına gönderilmiştir. Meclis Başkanlığı da ilgisi nedeni ile Dahiliye ve Maliye Encümenlerinden teşekkül eden muhtelit encümene havale etmiştir. Muhtelit encümen teklif üzerindeki incelemelerini tamamlayarak 15 Aralık 1935 tarihli bir mazbata hazırlamıştır. Bu encümende Nakiye Elgün de yer almıştır. Muhtelit encümen esas itibarıyla kanun teklifini kabule şayan görmüştür. Kanun maddelerinde bazı kelime değişiklikleri yapmıştır. Arazi ve bina vergilerinden ayrılmakta olan tayyare vergisinin bundan sonra özel idarelerce alınması gerektiğini belirtmiştir.

Özel idarelere ait vergi ve resimlerin tahsilinde tahsilat komisyonu görevini yapacak heyete vali ve kaymakamların başkanlık etmesi uygun görülmemiştir. Vilayet özel idarelerinin sayım ve kazanç vergilerinden aldıkları hisselere karşılık arazi ve bina vergilerinin tamamının kendilerine devrolunması yüzünden gelirlerinde ortaya çıkacak azalmayı giderici tedbirlerden olmak üzere 9. maddede düzenleme yapılması önerilmiştir (TBMM.ZC, 23 Aralık 1935, s. 56).

\subsection{Bina Vergisi Kanunu'nun Bazı Maddelerinin Değiştirilmesine Dair Kanun Layihası hakkında muhtelit encümen mazbatası}

Maliye Vekaleti tarafından hazırlanan kanun teklifi 2 Kasım 1935 tarihinde Başbakan İsmet İnönü imzası ile meclis başkanlığına gönderilmiştir. Meclis Başkanlığı ise Dahiliye ve Maliye encümenleri üyelerinden oluşan bir muhtelit komisyon oluşturmuştur. $\mathrm{Bu}$ encümene Nakiye Elgün de seçilmiştir. Muhtelit Encümen, Maliye Bakanlığı müsteşarının ve Dahiliye vekaleti mahalli idareler genel müdürünün de hazır bulundukları bir toplantıda layihayı değerlendirmiştir. Nihayetinde 18 Aralık 1935 tarihli bir mazbata hazırlanmıştır. Buna göre encümen esas itibarıyla kanun teklifini uygun görmüştür. Verginin özel idarelere ait olması 
dolayısıyla, umumi meclisin 15. maddeye göre teşkil edilecek yazım komisyonlarına kendi üyeleri arasından birini seçmesi doğru bulmamıştır. Bunun yerine vilayet halkından olmak şartıyla dışarıdan bir kişi seçmeleri uygun görülmüştür. Belediyelerin üyeleri dışından seçecekleri kişilerin de o belde halkından olması lüzumlu sayılmıştır. İstanbul'da kurulacak tahrir komisyonlarına seçilecek üyelerin ikisinin de umumi meclis tarafından seçilmesi zorunluluğu kabul edilmiştir. İstinaf komisyonlarına en büyük hususi idare memurunun veya vekilinin de iştirak etmesi faydalı bulunmuştur. Temyiz komisyonu gerekli görülmüştür. Ancak başkan ve üyelerinin seçilmesinin Bakanlar Kuruluna bırakılması istenmiştir (TBMM.ZC, 20 Ocak 1936, s. $80)$.

\subsection{Arazinin acele tahriri hakkında kanun layihası hakkında muhtelit encümen mazbatası}

Maliye Vekaleti tarafindan hazırlanan kanun teklifi 31 Ekim 1935 tarihinde Başbakan İsmet İnönü imzası ile meclis başkanlığına gönderilmiştir. Meclis Başkanlığı ise dahiliye ve maliye encümenleri üyelerinden oluşan bir muhtelit komisyon oluşturmuştur. $\mathrm{Bu}$ encümene Nakiye Elgün de seçilmiştir. Muhtelit Encümen, Maliye ve Dahiliye vekaletleri temsilcilerinin de hazır bulundukları bir toplantıda kanun teklifini incelemiştir. Nihayetinde 6 Ocak 1936 tarihli bir mazbata hazırlanmıştır.

Buna göre Arazi vergisinin ağır bir vergi niteliğinde olmamasına rağmen tahsilatının yüzde elliden yukarı çıkmaması, hatta bazı yerlerde yüzde otuza kadar düşmesi üzerinde durulmuştur. Bu verginin acilen yeniden yapılacak bir tahrirle tespit edilecek kıymetlere göre her tarafta aynı usulle alınması gerekli görülmüştür. Tahrir komisyonlarına seçilecek üyelerin umumi meclisten değil dışarıdan seçilmesi hususunda ikinci maddeye bir kayıt konmuştur. İstanbul'da belediyelerce seçilecek üyenin umumi meclis tarafından seçilmesi önerilmiştir. Arazi vergisinin özel idarelere devrolunmasından dolayı heyete hususi idareler müdür veya memurlarının katılması zorunlu görülmüştür. Arazilerinin sınırları hakkında kasten yanlış bilgi verenlerin sakladıkları yerin vegrisini iki sene süre ile üç kat ödemeleri için 14. maddeye hüküm konulmuştur (TBMM.ZC, 24 Ocak 1936, s. 89).

\subsection{Belediye kanununun 15.maddesinin 8. fikrasının tefsiri hakkında Muhtelit Encümen mazbatası}

Dahiliye Vekaleti tarafından hazırlanan tezkere Başbakan İsmet İnönü imzasıyla 10 Kasım 1936 tarihinde Meclis Başkanlığına gönderilmiştir. Başbakanlık yazısında tezkerenin yorumlanarak sonucun hükümete bildirilmesi istenilmiştir. Meclis Başkanlığ 1 ise tezkereyi yorumlaması için Nakiye Elgün'ün de üyesi bulunduğu Muvakkat Encümen'e havale etmiştir. Encümen, Sağlık Bakanlığı Sıhhat Müdürü Asım ve İçişleri Bakanlığı Hukuk müşaviri Ekrem Bey'in de hazır bulunduğu bir toplantıda tezkereyi değerlendirmiştir. Nihayetinde 18 Ocak 1937 tarihi mazbatasını oluşturmuştur. Buna göre manifatura ve tuhafiyeciler emrinde çalışan ve müşterilere ticaret malını gösteren ve ambalaj yapan işçilerin Belediye Kanunu'nun 15. maddesinin 8. fikrasında zikredilen halk ile temas eden hizmet erbabı işçiler arasında sayılamayacakları yönünde karar vermiştir (TBMM.ZC, 22 Ocak 1937, s. 63).

\subsection{Matbuat kanununun bazı maddelerinin değiştirilmesi hakkında kanun layihası hakkında muhtelit encümen mazbatası}

Dahiliye vekaletince hazırlanan kanun teklifi 22 Haziran 1938 tarihinde Başbakan Celal Bayar İmzası ile meclis başkanlığına gönderilmiştir. Meclis başkanlığ teklifin bir karma encümende görüşülmesini uygun görmüsstür. $\mathrm{Bu}$ yüzden ilgilerine binaen Adliye ve Dahiliye encümenlerinden görevlendirilen üyelerin yer aldığı bir muhtelit encümen oluşturmuştur. Dahiliye encümeni adına muhtelit encümende görevlendirilenler milletvekilleri arasında Nakiye Elgün de vardır.

Meclis Başkanlığ kanun teklifini 22 Haziran 1938 tarihinde muhtelit encümene havale etmiştir. Teklif, Dahiliye vekilinin de hazır bulunduğu bir toplantıda tartışılarak 27 Haziran 1938 
tarihli bir mazbata hazırlanmıştır. Buna göre layiha esas itibarıyla kabul edilmiştir. Matbuat kanununun diğer kanunlarla uyumlu olması gerektiği üzerinde durulmuştur. 9. maddede siyasi gazete veya mecmua çıkaranların bulundukları yerin nüfusuna göre beş yüz liradan beş bin liraya kadar milli bir bankanın kefaletini kapsayan teminat vermeleri mecburiyeti yerinde bir uygulama olacağı belirtilmiştir. Ancak, teminat mektubunun imtiyazlı karşılık sayılacağı hak ve alacaklar arasından kâğıt bedeli ve basım ücretinin çıkarılması istenmiştir. Teminatın gazeteye verilecek para cezalarını, yazarların, diğer görevlilerin ücretlerini, abone ve ilân bedellerini kapsaması yönünde yasa teklifine ilave yapılmıştır. Böylece hak sahihlerinin zarara uğramalarının önüne geçilmek istenmiştir. Yine mazbatada gazete ve mecmua sahiplerinin kötü şöhret sahibi olmamaları gerektiği hatırlatılmıştır. Gazete ve mecmua çıkarmak isteyenlerin beyanname vererek hükümetten ruhsatname almaları şartı getirilmiş, 17. maddeye bu hususta bir madde ilave edilmiştir (TBMM.ZC, 28 Haziran 1938, s. 331).

\subsection{Tiyatro ve sinemalardan devlet ve belediyelerce alınmakta olan damga, tayyare ve belediye resimleri ile darülaceze hissesinin miktarına ve sureti istifasına dair kanun layihası hakkında muhtelit encümen mazbatası}

Maliye vekaletince hazırlanan kanun teklifi 22 Haziran 1938 tarihinde Başbakan Celal Bayar İmzası ile meclis başkanlığına gönderilmiştir. Meclis Başkanlığı teklifin bir karma encümende görüşülmesini uygun görmüş̧ür. Bu yüzden ilgilerine binaen Bütçe, Dahiliye ve Maliye encümenlerinden görevlendirilen üyelerin yer aldığ bir muhtelit encümen oluşturmuştur. Dahiliye encümeni adına muhtelit encümende görevlendirilenler milletvekilleri arasında Nakiye Elgün de vardır.

Meclis Başkanlığı 22 Haziran 1938 günü kanun teklifini muhtelit encümene havale etmiştir. Kanun layihası Dahiliye ve Maliye vekilinin de hazır bulunduğu bir toplantıda tartışılarak 27 Haziran 1938 tarihli bir mazbata hazırlanmıştır. Buna göre tiyatro ve sinemalardan halkın tamamının faydalanması ve giriş ücretlerinin düşürülmesi uygun görülmüştür. Bunu sağlamak amacıyla tiyatro ve sinemaların bilet bedelleri üzerinden mahalline göre değişen yüzde 21 ile 28 arasındaki damga, tayyare ve belediye resmi ve darülaceze hissesinin her yerde seyyanen yüzde ona indirilmesi uygun bulunmuştur. Giriş ücretlerinin düşürülmesi görevi de belediyelere verilmiştir. Tiyatro ve sinemalarda bilet kullanılması mecburiyeti konulmuş, meccani veya tenzilatlı ücretle gireceklerden de vergi alınmasına karar verilmiştir. Encümen filmlerin yurt içine girişinde alınan gümrük vergisinden de indirim yapılmasını istemiş̧ir. Bunun için hükümete yetki verilmesi hususunda bir madde eklenmiştir. Layihanın ikinci maddesinde hususi bir pul kullanılacağı belirtilmişti. Encümen bu pullar bastırılana kadar vekaletin sürsajlı damga pulları kullanabileceğini, pul gönderilemeyen yerlerde de verginin nakit olarak tahsil edilebileceğini kabul etmiş, bu hususunda geçici bir madde eklemiştir (TBMM.ZC, 29 Haziran 1938, s. 314).

\subsection{Spor teşkilâtı hakkında kanun lâyihası hakkında muhtelit encümen mazbatası}

Kanun teklifi 23 Haziran 1938 tarihinde Başbakan Celal Bayar İmzası ile meclis başkanlığına gönderilmiştir. Meclis Başkanlığı teklifin bir karma encümende görüşülmesini uygun görmüştür. Bu yüzden ilgilerine binaen Bütçe, Dahiliye, Müdafaayı Milliye, Sthhat ve Maarif encümenlerinden görevlendirilen üyelerin yer aldığ 1 bir muhtelit encümen oluşturmuştur. Dahiliye encümeni adına muhtelit encümende görevlendirilenler milletvekilleri arasında Nakiye Elgün de vardır.

Meclis Başkanlığı 22 Haziran 1938 günü kanun teklifini muhtelit encümene havale etmiştir. Kanun layihası Dahiliye vekili Şükrü Kaya ve Başbakanlık müsteşarı Kemal Gedeleç'in de hazır bulunduğu bir toplantıda tartışılarak 27 Haziran 1938 tarihli bir mazbata hazırlanmıştır. Buna göre teklif bir kısım değişiklik önerileri ile birlikte kabul edilmiştir. Encümen "Spor Teşkilatı Kanunu" adını "Beden Terbiyesi Kanunu" olarak değiştirmiştir. Spor kulüplerinin kendileri tarafindan seçilen idare heyetlerinin bölgelerin tasdikinden geçirilmesi hakkındaki hükümet teklifi gençliğin hevesini kıracağı gerekçesiyle onaylanmamıştır. 2 maddede Hükümetin 
teklif ettiği, müstakil bütçe kaydı usul ve teamüle uygun görülmediğinden mülhak bütçe olarak tadil edilmiştir (TBMM.ZC, 29 Haziran 1938, s. 332).

\section{Sonuç}

Bilindiği üzere kadın hakları tarihi bir süreç içerisinde şekillenmiştir. Seçme ve seçilme hakkının verilmesi bu sürecin en önemli halkasını teşkil eder. Dünyanın pek çok ülkesinde kadınlar bu hakka sahip değilken Türkiye'de verilmiş olması önemlidir. Bu hak cumhuriyetin kurucusu Gazi Mustafa Kemal Atatürk'ün ve Türkiye Büyük Millet Meclisi'nin Türk kadınına bir hediyesidir.

$\mathrm{Bu}$ bağlamda Mustafa Kemal Atatürk'ün ve dönemin Cumhuriyet Halk Partisi teşkilatlarının kadın milletvekillerinin belirlenmesinde takip ettikleri yöntem ve kriterler de önemlidir. Makalede Nakiye Elgün örneğinden hareketle Türk kadınının seçme, seçilme ve temsil hakkını nasıl kullandığı ortaya konulmaya çalışılmıştır.

Makale metninden anlaşılacağı üzere ilk kadın parlamenterler halka örnek ve rehber olmaları için kültürlü ve medeni cesareti yüksek olduğu düşünülen bayanlardan seçilmişlerdir. Kadın milletvekili adaylarının belirlenmesinde Mustafa Kemal Atatürk ve Cumhuriyet Halk Fırkası merkez yönetimi etkili olmuştur. Taşradaki parti teşkilatlarının etkisi sınırlıdır.

Konumuzu teşkil eden Nakiye Elgün'ün milletvekili seçilene kadar Erzurum ile hiçbir ilgisi olmamıştır. İstanbul doğumlu olup Darülmuallimat mezunudur. Döneminin önde gelen eğitimcilerindendir. Son derece aktif bir kişiliğe sahiptir. Çok sayıda cemiyette faaliyet göstermiştir. Çeşitli toplantılarda ve mitinglerde yaptığı hitabeti ile dikkati çekmiştir. Bütün bu yönleri O'nun Cumhuriyet Halk Partisi tarafindan Erzurum'dan milletvekili adayı gösterilmesini ve seçilmesini sağlamıştır.

Diğer taraftan Nakiye Elgün ilk kadın milletvekilleri içinde öne çıkanlardandır. Geçmişte yaptığı üstün hizmetler ve karizması nedeni ile diğer kadın milletvekillerinin de saygısını kazanmıştır. Meclise en çok devam eden vekillerdendir. Her zaman olduğu gibi milletvekilliği görevini yürütürken de aşırı derecede titiz ve hassas davranmıştır.

Meclis genel kurulunda en çok konuşan kadın milletvekili odur. Diğer kadın milletvekillerindeki çekingenlik onda yoktur. O, 5. dönem milletvekilliği süresince 509 oylamaya katılmış, bunların tamamında kabul oyu kullanmıştır. Hiçbir oylamada çekimser kalması ya da ret oyu vermesi söz konusu olmamıştır. Bu tutumu iktidar ile tam bir uyum içerisinde olduğunu göstermektedir.

2 kanun teklifinde ve iki takrirde imzası vardır. Dahiliye Encümeninde görev yapmış olup toplam 35 mazbatanın hazırlanmasına katkı sağlamışır. Bunlardan 27'si Dahiliye Encümeni'ne aittir. 8'i ise bu encümen adına katıldığı muhtelit encümen mazbatalarıdır.

Sonuç olarak Nakiye Elgün kadınlara verilen siyasi hakları en verimli şekilde kullanabilen milletvekillerindendir. O'nun kendine güveni, azmi ve cesaretinin gerek dönemindeki gerekse daha sonraki kadın milletvekillerini etkilediğini söylemek mümkündür.

\section{Kaynakça}

Afetinan, A. (1982). Tarih Boyunca Türk Kadınının Hak ve Görevleri, İstanbul: Milli Eğitim Bakanlığı yayınları.

\section{Akşam Gazetesi}

Avcı, M. (2016). " Osmanlı Devleti'nde Kadın Hakları ve Kadın Haklarının Gelişimi İçin Mücadele Eden Öncü Kadınlar", Atatürk Üniversitesi Türkiyat Araştırmaları Enstitüsü Dergisi, 55, 225-254.

Cumhuriyet Gazetesi 
Duroğlu, S. (2007). Türkiye'de İlk Kadın Milletvekilleri, Türkiye'de İlk Kadın Milletvekilleri, (Yayımlanmamış yüksek lisans tezi), Ankara Üniversitesi Sosyal Bilimler Enstitüsü, Ankara.

Gövsa, İ. A. (1946). Türk Meşhurları Ansiklopedisi, İstanbul: Yedigün Neşriyat.

Güneş, İ. (2001). Türk Parlamento Tarihi (T.B.M.M. V. Dönem 1935-1939), C.2, Ankara: T.B.M.M. Vakfi Yayınları.

http://www.cocukhaklariizleme.org/cocuk-haklarinin-tarihcesi (ET: 10 Nisan 2020)

https://www.matematiksel.org/nakiye-elgun-osmanlidan-turkiyeye-bir-egitimcinin-ve-tarihteilk-cocuk-haklari-bildirgesinin-yazarinin-oykusu/(ET: 10 Nisan 2020)

Kurnaz, Ş. (1992). Cumhuriyet Öncesinde Türk Kadını, 1839-1923), İstanbul: Milli Eğitim Bakanlığı yayınları.

\section{Kurun Gazetesi}

Milliyet Gazetesi

Önen, Y, R. (10 Şubat 1935)." Erzurum Saylavı Bayan Nakiye Anlatıyor", Kurun, 6141-79.

Öztürk, C. (2012)."İdadi" Türkiye Diyanet Vakfi İslam Ansiklopedisi 21, İstanbul: Türkiye Diyanet Vakfı Yayınları, 464-466.

Öztürk, M. (2014). "Osmanlı'dan Cumhuriyete Bir Eğitimci: Nakiye Elgün", Atatürk Dergisi, $3(2), 29-46$.

Resmi Gazete, Sayı: 3553, 3773.

Son Posta Gazetesi

Şapolyo, E, B. (1968). İstiklal Savaşı ve Edebiyat Tarihi (Milli Mücadelenin Edebi Vesikaları 1919-1923, İstanbul: Ak Kitabevi.

Topçuoğlu, O. ve Topçuoğlu, T. (1984). Cumhuriyet Döneminde Olaylarda ve Mesleklerde Basınımızda Yer Alan Illk Kadınlar, Ankara.

Topkapı Fukaraperver Cemiyeti (2008). 1908-2008, İstanbul.

Toros, T. "Niçin Evlenemediler", Milliyet, 14 Haziran 1986.

Türkiye Büyük Millet Meclisi Arşivi

Türkiye Büyük Millet Meclisi Zabıt Ceridesi, Devre V, C.1-29.

Ulus Gazetesi

Üçüncü Türk Dil Kurultayı 1936 Tezler, Müzakere Zabıtlar, (1937). İstanbul: Devlet Basımevi.

Yalçın, H. (2019). Cumhuriyet Dönemi Kadın İmajı İş̧ası (1928-1938), (Yayımlanmamış Yüksek Lisans Tezi), Hacettepe Üniversitesi Atatürk İlkeleri ve İnk1lâp Tarihi Enstitüsü, Ankara.

\section{ETIKK ve BİLIMSEL İLKELER SORUMLULUK BEYANI}

$\mathrm{Bu}$ çalışmanın tüm hazırlanma süreçlerinde etik kurallara ve bilimsel atıf gösterme ilkelerine riayet edildiğini yazar(lar) beyan eder. Aksi bir durumun tespiti halinde Afyon Kocatepe Üniversitesi Sosyal Bilimler Dergisi'nin hiçbir sorumluluğu olmayıp, tüm sorumluluk makale yazarlarına aittir. 